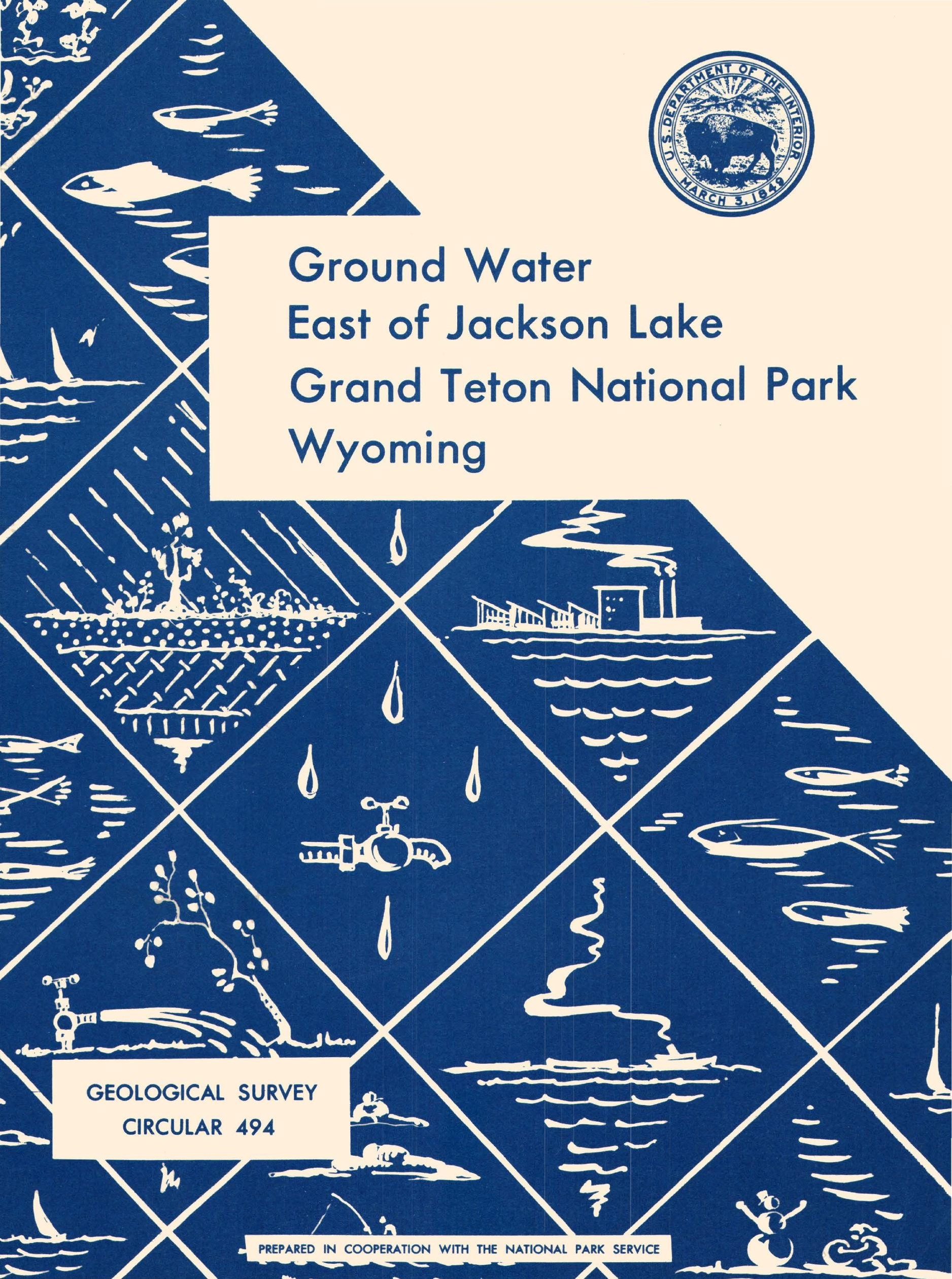




\section{Ground Water East of Jackson Lake Grand Teton National Park, Wyoming}

By Laurence J. McGreevy and Ellis D. Gordon

$$
\lambda
$$

Geological Survey Circular 494

Prepared in cooperation with the National Park Service 
United States Department of the Interior

STEWART L. UDALL, SECRETARY

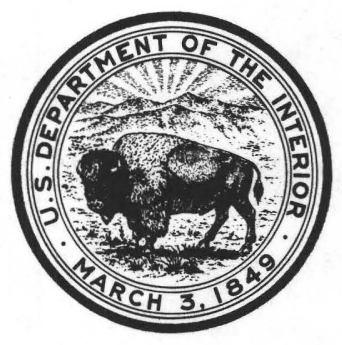

Geological Survey

THOMAS B. NOLAN, DireCTOR

父

Free on application to the U.S. Geological Survey, Washington, D. C. 20242 
Page

Abstract

Introduction

Geographic setting -

Previous investigations

Acknowledgments

Well-numbering system

Need for additional water supplies..

Summary of geology

Stratigraphy

Structure

Glaciation

Ground water

Geologic units and their water-

bearing possibilities ...........

Units of Cretaceous and Tertiary

age

Units of Quaternary age ....... 9

Alluvium ................. 9

Lacustrine deposits at Buffalo

Fork

Glacial deposit

deposits

Undifferentiated deposits of

Quaternary age...........
Ground water-Continued

Movement of ground water........

Special areas of investigation ......

Buffalo Fork area............

Pilgrim Creek valley area .......

Jackson Lake Campground area . -

Colter Bay reservoir area.......

Lizard Point Campground area...

Results of pumping tests ......

Buffalo Fork test ............

Pilgrim Creek valley tests ....

Jackson Lake Campground tests

Lizard Point Campground test

Page

14

14

15

18

19

20

21

21

21

23

23

24

24

Possibilities for future ground-water development ..................... Deposits of Quaternary age ........ Deposits of pre-Quaternary age ....

Selected references................
24

24

27

27

\section{ILLUSTRATIONS}

Plate 1. Map showing wells, test holes, springs, and areas where additional water might be developed from Quaternary deposits, Jackson Lake area, Wyoming. .... - In pocket

Figure 1. Index map of northwestern Wyoming

2. Diagram of well-numbering system

3. Generalized geologic map

4. Graph showing the stage of Jackson Lake and water levels in nearby wells _._. 15

5. Graphic logs of test wells and test holes

6. Diagrammatic geologic section near the junction of the Snake and Buffalo Fork Rivers

7. Graph showing the relation of the water level in well 45-114-23ccd to the stage of the Snake River

8. Graph of water-level and discharge fluctations of test wells

\section{TABLES}

Table 1. Generalized stratigraphic section of rocks of Cretaceous and Tertiary age

3. Records of wells, test wells, and springs east of Jackson Lake

4. Depths to water in observation wells in the Pilgrim Creek valley

5. Specific capacity of test wells

6 . Chemical analyses of ground waters east of Jackson Lake 


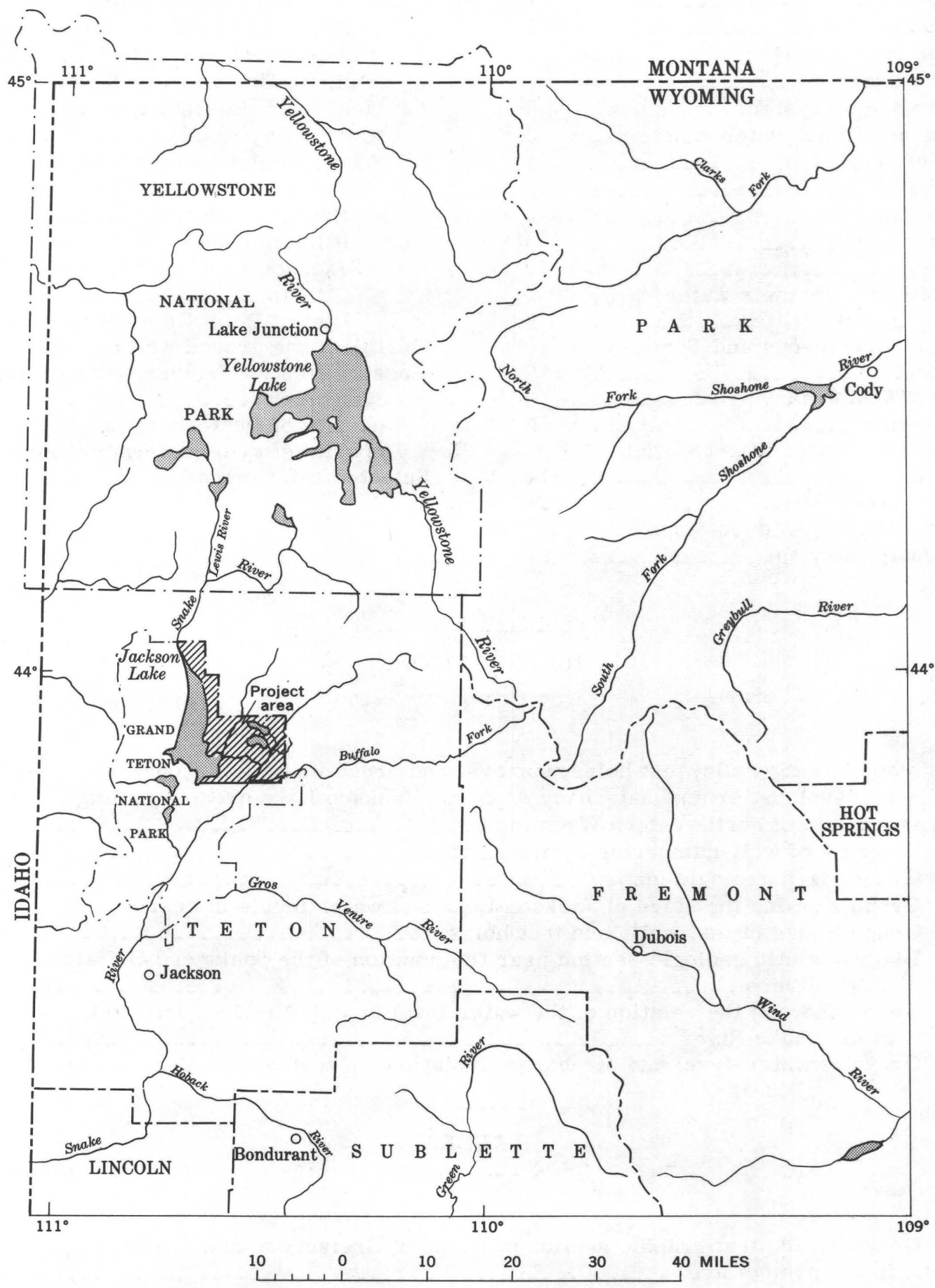

Figure 1. - Map of northwestern Wyoming showing location of project area. 


\title{
Ground Water East of Jackson Lake, Grand Teton National Park, Wyoming
}

\author{
By Laurence J. McGreevy and Ellis D. Gordon
}

\section{ABSTRACT}

The project area, which lies east of and adjacent to Jackson Lake is on the downthrown eastern block of the Teton fault, a normal fault that trends northward along the west edge of Jackson Lake. Rocks of pre-Cretaceous age are deeply buried beneath this area. Sedimentary rocks of Cretaceous age and sedimentary and volcanic rocks of Tertiary age, which have an aggregate thickness of about 30,000 feet, are exposed in the northern and eastern parts of the area. Along most of the east side of Jackson Lake, unconsolidated glacial and interglacial deposits of Quaternary age overlie the rocks of Cretaceous and Tertiary age. The unconsolidated deposits were penetrated by test drilling to a depth of $206 \mathrm{feet}$, but the maximum thickness is probably much greater.

Test wells were drilled in five localities to evaluate the deposits of Quaternary age as possible sources of ground water for National Park Service facilities. In the Pilgrim Creek valley, test wells were capable of yielding $200 \mathrm{gpm}$ (gallons per minute); properly constructed production wells could obtain much greater yields. Test wells at Lizard Point and Jackson Lake Campgrounds yielded more than $100 \mathrm{gpm}$, and a test well near the confluence of the Buffalo Fork and Snake rivers yielded $30 \mathrm{gpm}$. A test hole drilled in the $\mathrm{NW} / 4$ sec. 36 , T. $46 \mathrm{~N}$., R. 115 W., was dry at 200 feet.

Unconsolidated deposits of Quaternary age are the most promising source of additional ground water. Because of the extreme range in grain size and sorting, these deposits vary greatly in permeability. Their saturated thickness ranges from 0 'to more than 130 feet and changes seasonally; variations of as much as 36 feet were measured (1961-62) in the Pilgrim Creek valley. In most localities where deposits of Quaternary age are present, small to moderate ground-water supplies can be developed; larger ground-water supplies can be developed in parts of the Pilgrim Creek valley.

One well taps the Bivouac Formation of Late Pliocene or Pleistocene age, but no other wells are known to tap rocks of possible pre-Quaternary age. The Harebell Formation and Bacon Ridge Sandstone of Late Cretaceous age and the Bivouac Formation offer the best possibilities for development of additional water supplies from the consolidated rocks.

Chemical analyses of water samples from 11 wells in the deposits of Quaternary age and 1 well in the Bivouac Formation indicate that the water is of generally good quality for drinking and most other purposes. Water from one well tapping lacustrine(?) sand had a dissolved-solids content of 321 ppm (parts per million); all other samples had from 87 to 145 ppm.

\section{INTRODUCTION}

At the request of the National Park Service, the Ground Water Branch of the U.S. Geological Survey investigated ground-water conditions in that part of Grand Teton National Park east of Jackson Lake (fig. 1). Fieldwork was done in the summer of 1961, and supplemental water-level measurements were made in 1962. The investigation was concentrated in five localities where additional groundwater supplies are needed. A brief recon naissance of other parts of the area was made to establish regional geologic and hydrologic relations and to aid in locating ground water for possible future needs.

\section{GEOGRAPHIC SETTING}

The area included in this investigation is in the northern part of Jackson Hole-a broad, relatively flat valley surrounded by mountain ranges and highlands; this valley extends from the north end of Jackson Lake southward almost to the confluence of the Hoback and Snake Rivers (fig. 1). The floor of Jackson Hole slopes gently from an altitude of about 7,000 feet in the north to about 6,000 feet in the south, and the surrounding highlands and mountains rise 3,000 to 7,000 feet above the valley floor. The major drainage, the Snake River, flows southward through Jackson Hole and then cuts westward through the mountains into Idaho. The topographic features and drainage of the project area are shown on plate 1 , and regional drainage systems are shown in figure 1.

The average annual precipitation at the Moran weather station near Jackson Lake 
Dam was 21.28 inches during 1931-60. Precipitation in the mountains and highlands is greater than at the weather station, and average surface runoff from the drainage basin is more than 20 inches per year. The highest monthly long-term mean temperature at the weather station is $57.4^{\circ} \mathrm{F}$ for July, and the lowest is $11.3^{\circ} \mathrm{F}$ for January. The annual long-term mean temperature is $34.2^{\circ} \mathrm{F}$.

\section{PREVIOUS INVESTIGATIONS}

Many geologists, beginning with F. H. Bradley in 1872 and O. H. St. John in 1877, have studied various aspects of the geology of the area, but little mention has been made of ground water. The glacial study by Fryxell (1930) and various works dealing with general regional geology by J. D. Love and his associates have been of particular value to the authors. (See "Selected references.")

\section{ACKNOWLEDGMENTS}

The authors express their appreciation to the residents of the area, to the personnel of the National Park Service and the Bureau of Reclamation, and to others who aided in this study. Phillip Schultz, former park engineer, supervised the test drilling in Grand Teton National Park for the Park Service. Robert Kranenberg, utilities and maintenance foreman for the Park, provided valuable assistance and equipment. The assistance of $\mathrm{J}$. D. Love, geologist, U.S. Geological Survey; is gratefully acknowledged. He provided geologic and hydrologic data, discussed the geology with the authors, reviewed the geologic framework of the report, and aided in many other ways.

\section{WELL-NUMBERING SYSTEM}

Wells are numbered according to their location within the Bureau of Land Management's system of land subdivision. All wells are in the northwest quadrant of the sixth principal meridian and base-line system. The first numeral of a well number indicates the township, the second the range, and the third the section in which the well is located. The letters which follow the section number indicate the location of the well within the section. The first letter denotes the quarter section, the second the quarter-quarter section, and the third the quarter-quarter-quarter section. The subdivisions of the section are lettered $\mathrm{a}, \mathrm{b}, \mathrm{c}$, and d, counterclockwise, beginning with (a) in the northeast quarter. Where more than one well is in the same quarter-quarterquarter section, consecutive numbers beginning with 1 are added to the well number. Thus, well 45-114-26abb2 is the second well located in the NW $\frac{1}{4} \mathrm{NW} \frac{1}{4} \mathrm{NE} \frac{1}{4}$ sec. $26, \mathrm{~T} .45 \mathrm{~N}$., R. $114 \mathrm{~W}$., of the sixth principal meridian and base-line system (fig. 2).

Much of the northern part of the project area has not been surveyed for inclusion in the landline network of the Bureau of Land Management's system of land subdivision. Wells in this unsurveyed area have been numbered by location in the same manner as those in the surveyed area except that a grid system has been substituted for actual landlines. An asterisk (*) representing the word "unsurveyed" has been added to these well numbers. Springs and test holes have been

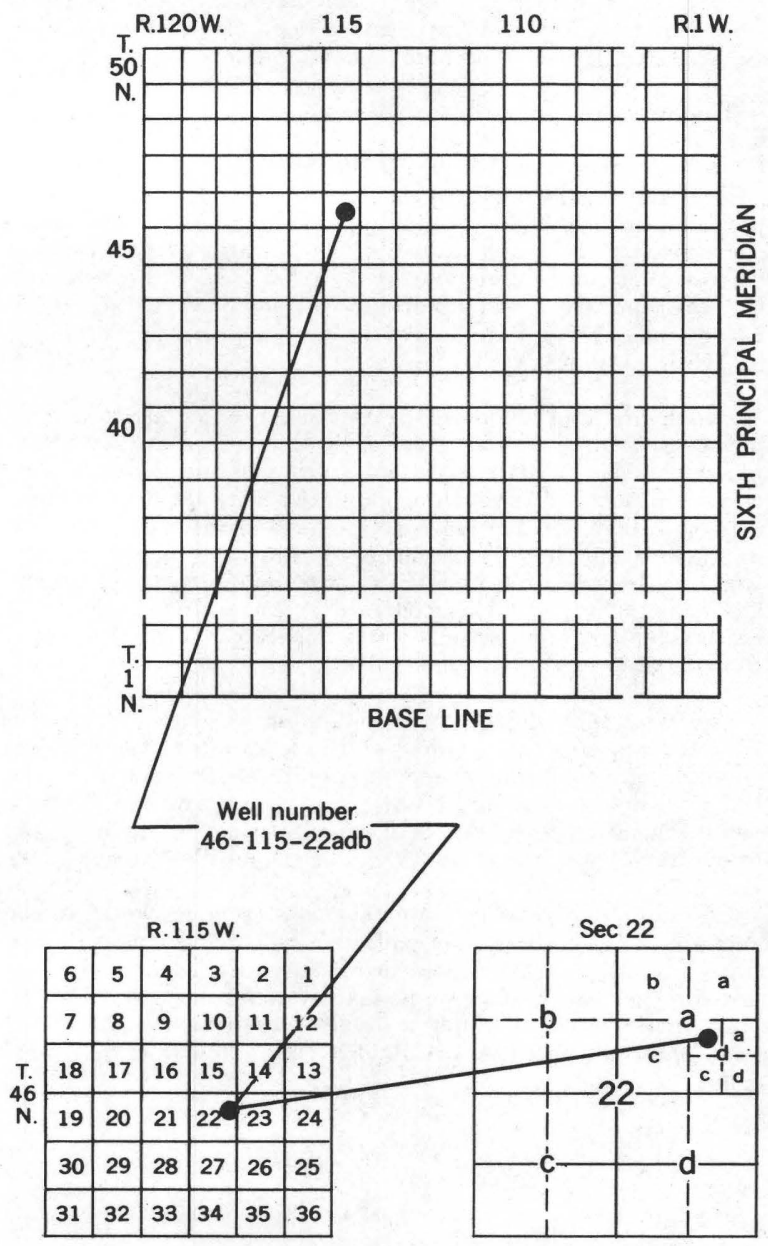

Figure 2.-Well-numbering system. 
assigned numbers according to their locations in the same manner as wells.

\section{NEED FOR ADDITIONAL WATER SUPPLIES}

In 1961 the primary water supply for the Colter Bay and Jackson Lake Lodge developments was obtained from a diversion of spring water (NE $\frac{1}{4} \mathrm{sec} .20$ ?, T. 46 N., R. 114 W., unsurveyed) on the east side of Pilgrim Creek valley north of the Grand Teton National Park boundary. The water was stored in two 500,000-gallon enclosed reservoirs, one near Colter Bay and the other near Jackson Lake Lodge. During times of maximum use, the flow of the spring, an average of $140 \mathrm{gpm}$ (gallons per minute), was insufficient. At these times, a supplemental supply of about $200 \mathrm{gpm}$ for Jackson Lake Lodge was obtained from a group of springs (45-114-8ca) in the seep area just east of the lodge.

Water use in the Colter Bay area and at Jackson Lake Lodge is steadily increasing, and shortages have begun to develop. The Park Service estimates that about $200 \mathrm{gpm}$ of additional water is required to satisfy immediate needs and that a considerably larger water supply eventually will be required.

Jackson Lake Campground in 1961 received its water from well 45-115-24cdd at Signal Mountain Lodge. Water was pumped to a 15,000-gallon reservoir and was fed by gravity to the campground and lodge. Additional water will be needed for expansion of the campground. Water for the Lizard Point Campground in 1961 was carried in by campers or was obtained from the small springs along the high-water line of Jackson Lake. Modernization of the campground will require a source capable of yielding at least $15 \mathrm{gpm}$. The employee residence near the junction of the Snake and Buffalo Fork Rivers was supplied by a small-capacity well (45-114-26bab) at the residence. A larger yield, possibly 40 gpm or more, may be needed if additional facilities are constructed in this area.

The feasibility of satisfying the preceding water-supply requirements with ground water is discussed in the section on results of pumping tests. Future developments may require other water supplies; the concluding section of this report briefly discusses the possibilities of developing ground water in the whole area.

\section{SUMMARY OF GEOLOGY}

This brief summary of the geology is based mainly on the work of Love $(1956 b, c)$. For more complete geologic information, the reader is referred to "Selected references" at the end of this report. Lithologic descriptions and stratigraphic relations of units of Cretaceous and Tertiary age are given in table 1; units of Quaternary age are discussed in the section on "Geologic units and their water-bearing possibilities."

\section{STRATIGRAPHY}

Deposits exposed in the project area range in age from Early Cretaceous to Quaternary. Glacial and alluvial deposits of Quaternary age occur in much of the area (fig. 3). PreCretaceous formations are deeply buried and are not discussed.

Cretaceous formations are composed mostly of shale and sandstone beds that were depos ited in a generally conformable series. Beginning near the end of the Cretaceous Period and continuing through the Tertiary, deposition was occasionally interrupted by structural movement and erosion, and unconformities are fairly numerous. The rocks of latest Cretaceous (Harebell Formation) and Tertiary age are generally much coarser grained than older rocks, and conglomerate is common. Local volcanic activity began during Eocene time, and formations of late Tertiary age contain much material of volcanic origin. (See table 1.) Glacial, fluvial, and lacustrine deposits of Quaternaryage range fromboulders to clay. Loess and volcanic ash also occur as beds or are mixed with other sediments.

\section{STRUCTUPE}

The Teton fault, the main structural feature of northern Jackson Hole, has been a major factor in the depositional environment during late Tertiary and Quaternary time. The northward-trending trace of the fault lies along the west side of northern Jackson Hole immediately west of the project area. This normal fault is about 40 miles long and has a maximum vertical displacement of about 20,000 feet. Downdropping of the eastern fault block accounted for much, but not all, of the displacement. The area investigated, which is on the eastern fault block, was downdropped and tilted westward. 


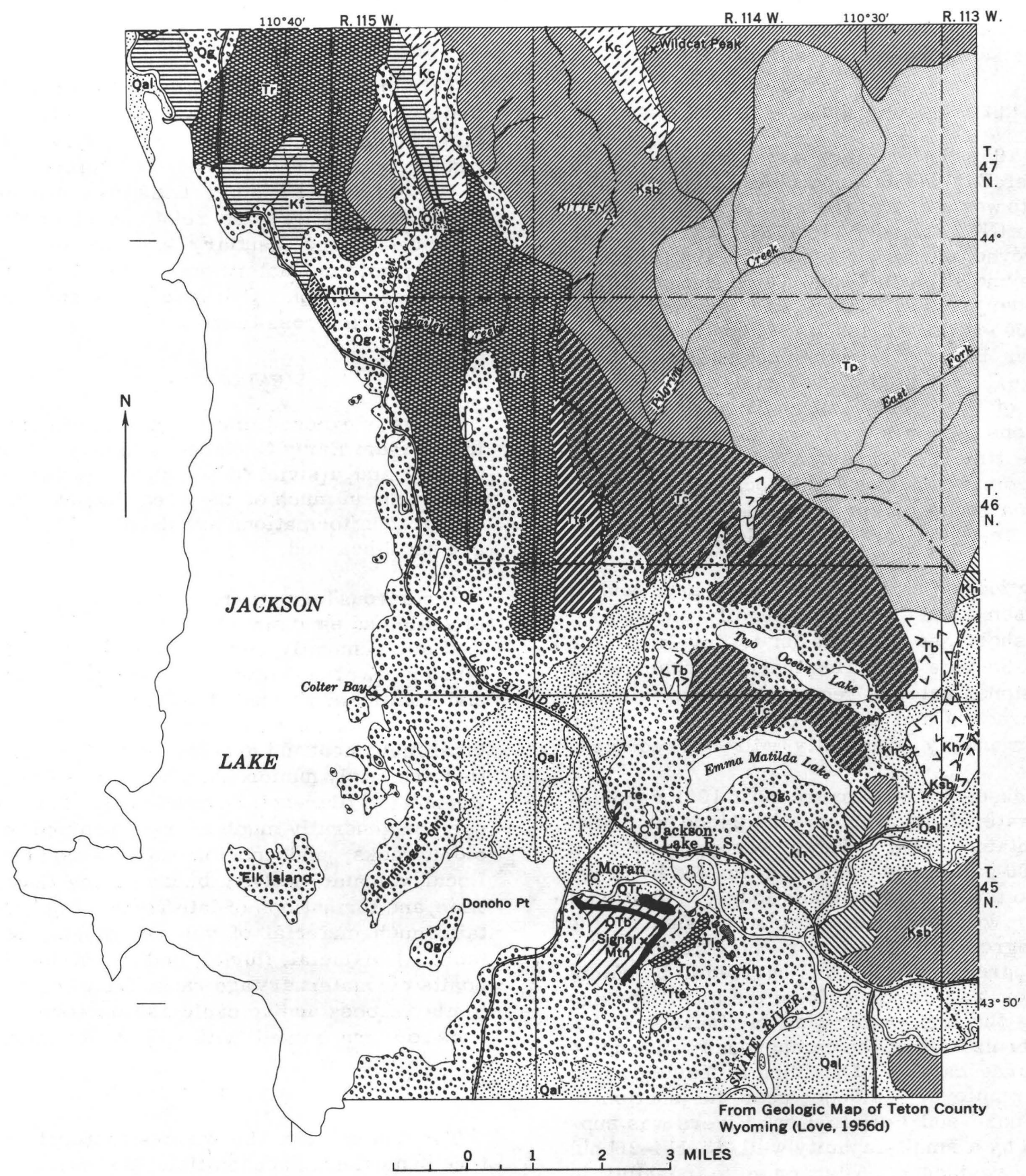

Figure 3.-Generalized geologic map.

Most of the movement along the Teton fault zone occurred in late Pliocene time, but movement has continued intermittently. Near the north end of the Teton fault zone, in the vicinity of the south boundary of Yellowstone National Park, movement has been appreciable since the formation of recognizable glacial features. Love (1961, p. 1,759-62) re ported 150 to 200 feet of displacement on each of two main faults in that vicinity. Elsewhere, more recent movement is indicated by anomalous stream patterns near the fault zone, by fault scarplets in young glacial deposits, and by occasional earthquake shocks recorded in recent years (Love and de la Montagne, 1956). Aerial photographs show an apparent fault trace that seems to displace glacial deposits along the east side of Pilgrim Creek valley. 


\section{EXPLANATION}
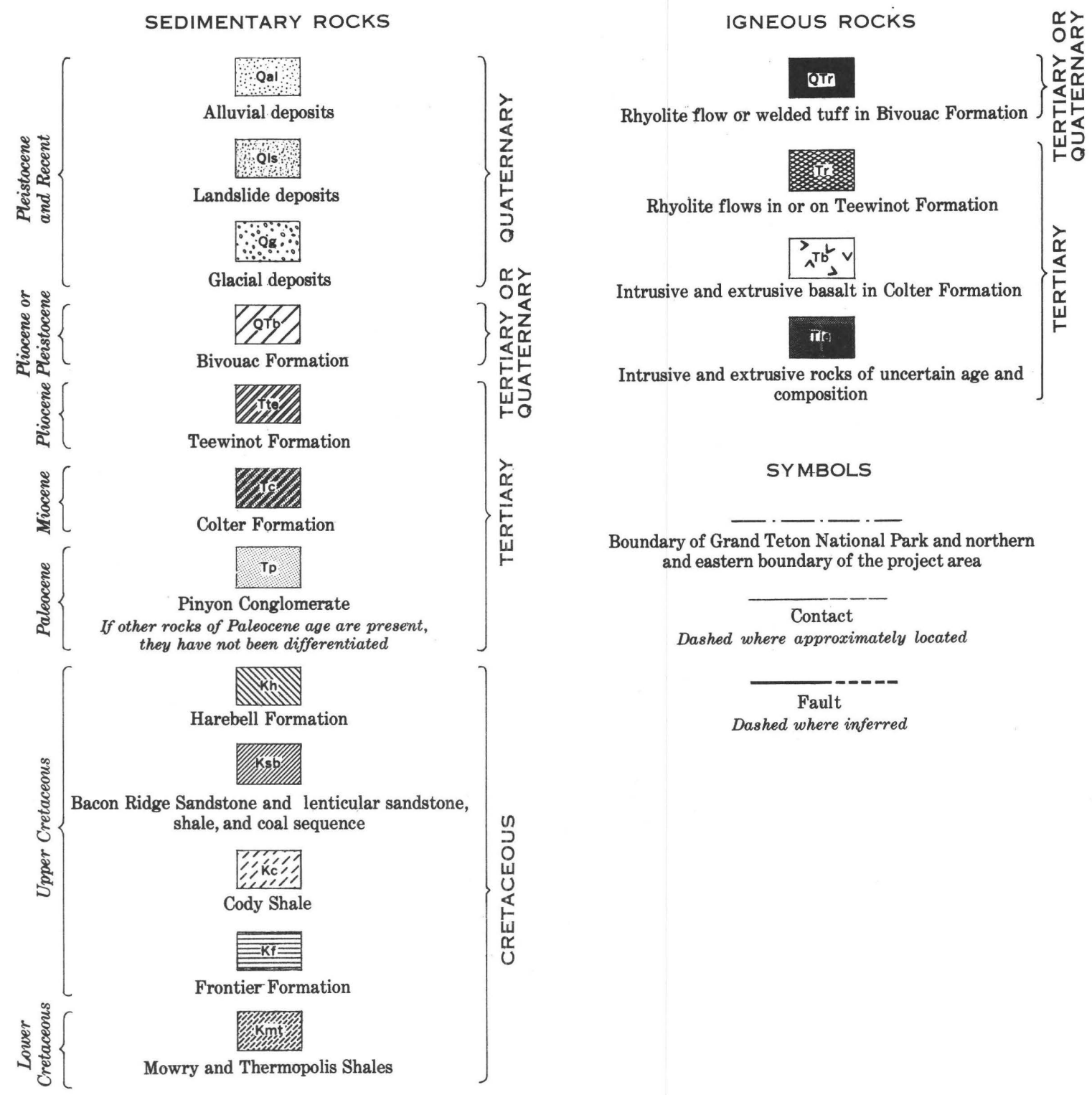

Figure 3.-Explanation.

\section{GLACIATION}

Three distinct glaciations-Buffalo, Bull Lake, and Pinedale-were recognized by Blackwelder (1915) in the Wind River Range (about 70 miles southeast of Jackson Hole) and in parts of Jackson Hole. Fryxell (1930), using Blackwelder's nomenclature, described the glacial features of Jackson Hole. Much of the following discussion is based upon Fryxell's work. Minor post-Pinedale glaciation in the mountain valleys did not reach the floor of Jackson Hole and therefore will not be discussed here.
The oldest recognizable glacial features in Jackson Hole have been attributed to the Buffalo of Blackwelder (1915). Piedmont ice sheets moving southward from Yellowstone National Park covered most of Jackson Hole and scoured deep grooves in the bedrock. These grooves control much of the drainage in the northern part of the project area. Recent glacial studies have shown that in the Wind River Range the "Buffalo glacial stage" was not a single glaciation but at least three separate glaciations (Richmond, 1962); consequently, the term "Buffalo" has been abandoned by the Geological Survey. In Jackson 
Table 1.-Generalized stratigraphic section of rocks of Cretaceous and Tertiary age in the project area

\begin{tabular}{|c|c|c|c|c|c|c|}
\hline 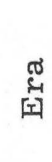 & 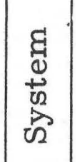 & Series & $\begin{array}{c}\text { Geologic } \\
\text { unit }\end{array}$ & $\begin{array}{l}\text { Approximate } \\
\text { maximum } \\
\text { thickness } \\
\quad \text { (feet) }\end{array}$ & Physical Characteristics $^{1}$ & Water-bearing possibilities ${ }^{2}$ \\
\hline & 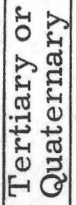 & $\begin{array}{l}\text { Pleisto- } \\
\text { cene or } \\
\text { upper } \\
\text { Pliocene }\end{array}$ & $\begin{array}{c}\text { Bivouac } \\
\text { Formation }\end{array}$ & $1,000+$ & $\begin{array}{l}\text { Poorly cemented conglomerate of quart- } \\
\text { zite and mafic volcanic rock fragments; } \\
\text { minor amounts of soft sandstone, silt- } \\
\text { stone, claystone, and pumicite, and a } \\
\text { bed of welded rhyolite tuff. }\end{array}$ & $\begin{array}{l}\text { Good. One well (45-114-19baa) obtains } \\
\text { a moderate quantity of water of good } \\
\text { quality (table 6) from conglomerate } \\
\text { and sandstone. }\end{array}$ \\
\hline
\end{tabular}

Angular unconformity. Major movement began along Teton fault zone. Rocks were folded, tilted southwestward, and eroded.

\begin{tabular}{c|c|c|l|l} 
Middle & & $\begin{array}{l}\text { Tuff, pumicite, marl, claystone, lime- } \\
\text { stone, sandstone, and conglomerate } \\
\text { associated with rhyolite flows, Outcrops } \\
\text { within the project area are mainly } \\
\text { yellow and white pumicite and some } \\
\text { obsidian sandstone interbedded with } \\
\text { purple, red, and brown rhyolite flows } \\
\text { and welded tuff. }\end{array}$ & $\begin{array}{l}\text { Poor. One domestic well several miles } \\
\text { south of the project area is reported to } \\
\text { tap this formation. In general, how - } \\
\text { ever, the formation is probably a poor } \\
\text { aquifer. }\end{array}$ & 5,000 \\
\hline
\end{tabular}

Angular unconformity. Rocks were tilted and eroded.

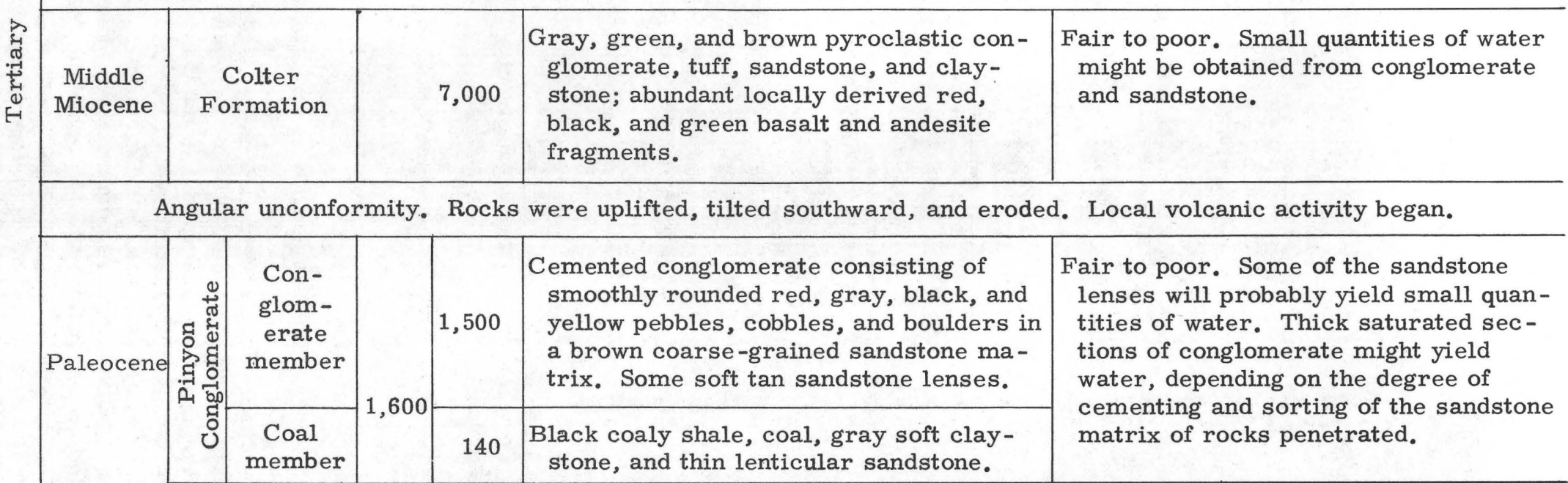




\begin{tabular}{|c|c|c|c|c|c|c|}
\hline & & & Angular unco & y. Nor & rthwestward-trending folds and faults forme & ed, and rocks were eroded. \\
\hline & & & $\begin{array}{l}\text { Harebell } \\
\text { Formation }\end{array}$ & 5,000 & $\begin{array}{l}\text { Lenticular quartzite-cobble conglomerate } \\
\text { and green, olive-drab, and gray sand- } \\
\text { stone, siltstone, claystone, and shale. }\end{array}$ & $\begin{array}{l}\text { Good. Contains several permeable sand- } \\
\text { stone beds that probably would yield } \\
\text { small to moderate quantities of water. } \\
\text { The quality of the water is probably } \\
\text { inferior to that in the Quaternary } \\
\text { deposits. }\end{array}$ \\
\hline & & & & Angu & lar unconformity. Rocks were warped and & eroded. \\
\hline & & 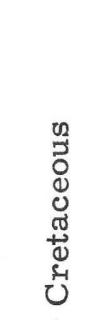 & $\begin{array}{l}\text { Lenticular } \\
\text { sandstone, } \\
\text { shale, and } \\
\text { coal sequence }\end{array}$ & 3,400 & $\begin{array}{l}\text { Gray lenticular sandstone and soft gray to } \\
\text { brown shale; numerous coal beds, mostly } \\
\text { in the lower part of the sequence. }\end{array}$ & $\begin{array}{l}\text { Fair to poor. Sandstone beds in the } \\
\text { upper part of the sequence would prob- } \\
\text { ably yield small quantities of water, } \\
\text { but they are separated by thick sections } \\
\text { of shale. Less sandstone occurs in the } \\
\text { lower coaly part of the sequence. The } \\
\text { water is probably much poorer in qual- } \\
\text { ity than that in the Quaternary deposits. }\end{array}$ \\
\hline $\begin{array}{l}0 \\
0 \\
0 \\
0 \\
0 \\
0 \\
\sum_{i}^{2}\end{array}$ & 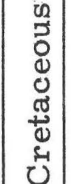 & 范 & $\begin{array}{l}\text { Bacon Ridge } \\
\text { Sandstone }\end{array}$ & 1,300 & $\begin{array}{l}\text { Light-gray massive sandstone, gray shale, } \\
\text { and coal. }\end{array}$ & $\begin{array}{l}\text { Good. Small to moderate quantities of } \\
\text { water could probably be obtained from } \\
\text { beds of sandstone, some of which } \\
\text { locally are several hundred feet thick. }\end{array}$ \\
\hline & & & Cody Shale & 2,200 & $\begin{array}{l}\text { Gray soft shale and shaly sandstone; many } \\
\text { lenticular glauconitic sandstone beds and } \\
\text { some thin bentonite beds. }\end{array}$ & $\begin{array}{l}\text { Poor. Small quantities of water might } \\
\text { be obtained from beds of sandstone, }\end{array}$ \\
\hline & & & $\begin{array}{l}\text { Frontier } \\
\text { Formation }\end{array}$ & 1,100 & $\begin{array}{l}\text { Gray to black shale and gray sandstone; } \\
\text { thin persistent green, white, and pink } \\
\text { bentonite and porcelanite beds in lower } \\
\text { part. }\end{array}$ & $\begin{array}{l}\text { sections of shale. The water is prob- } \\
\text { ably of much poorer quality than that } \\
\text { in the Quaternary deposits. }\end{array}$ \\
\hline & & 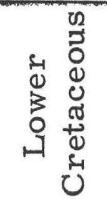 & Mowry Shale & 700 & $\begin{array}{l}\text { Black hard siliceous shale interbedded } \\
\text { with lesser amounts of black soft fissile } \\
\text { shale, bentonite, and silicified tuff and } \\
\text { sandstone. }\end{array}$ & Probably not an aquifer. \\
\hline
\end{tabular}


Table 1.-Generalized stratigraphic section of rocks of Cretaceous and Tertiary age in the project area -Continued

\begin{tabular}{|c|c|c|c|c|c|c|c|c|}
\hline 党 & 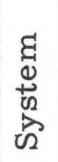 & Series & \multicolumn{2}{|c|}{$\begin{array}{l}\text { Geologic } \\
\text { unit }\end{array}$} & \multicolumn{2}{|c|}{$\begin{array}{l}\text { Approximate } \\
\text { maximum } \\
\text { thickness } \\
\quad \text { (feet) }\end{array}$} & Physical Characteristics ${ }^{1}$ & Water-bearing possibilities ${ }^{2}$ \\
\hline \multirow{4}{*}{ 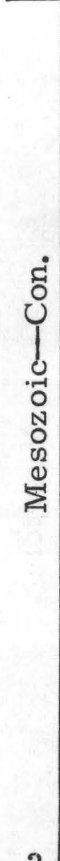 } & \multirow{5}{*}{ 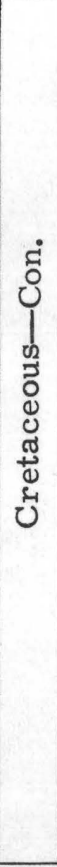 } & \multirow{4}{*}{ 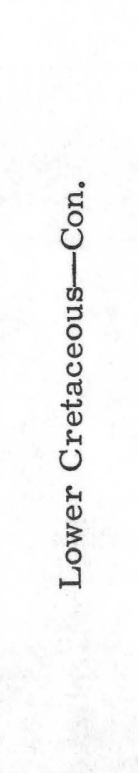 } & \multirow{2}{*}{ 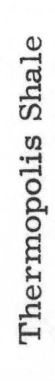 } & $\begin{array}{l}\text { Muddy } \\
\text { Sandstone } \\
\text { Member }\end{array}$ & \multirow[t]{2}{*}{300} & 90 & $\begin{array}{l}\text { Gray and greenish-gray very fine to } \\
\text { medium grained sandstone, lesser } \\
\text { amounts of black shale, and thin layers } \\
\text { of bentonite. Quartzitic in southern } \\
\text { Yellowstone National Park and in the } \\
\text { Snake River Canyon. }\end{array}$ & $\begin{array}{l}\text { Poor. Small quantities of water might } \\
\text { be obtained from beds of sandstone. }\end{array}$ \\
\hline & & & & $\begin{array}{l}\text { Lower } \\
\text { shale } \\
\text { member }\end{array}$ & & 220 & $\begin{array}{l}\text { Black soft fissle shale; thin partings of } \\
\text { gray siltstone. }\end{array}$ & Probably not an aquifer. \\
\hline & & & & & & 150 & $\begin{array}{l}\text { "Rusty beds" consisting of olive-green, } \\
\text { gray, and buff thin-bedded sandstone } \\
\text { interbedded with dark-gray to black silty } \\
\text { shale. Quartzitic in southern Yellow- } \\
\text { stone National Park. }\end{array}$ & Fair to poor. Small quantities of water \\
\hline & & & $\begin{array}{l}\mathrm{Mc} \\
\mathrm{Fc} \\
\text { un }\end{array}$ & $\begin{array}{l}\text { rison(?) } \\
\text { rmations } \\
\text { divided }{ }^{3}\end{array}$ & 700 & 350 & $\begin{array}{l}\text { Variegated red, gray, purple, and pink } \\
\text { claystone; thin beds of hard nodular } \\
\text { limestone. }\end{array}$ & $\begin{array}{l}\text { might be obtained from beds of sand- } \\
\text { stone in upper and lower parts, but the } \\
\text { "variegated" section is probably not an } \\
\text { aquifer. }\end{array}$ \\
\hline- & & - $?-?$ & & & & 250 & $\begin{array}{l}\text { Buff and gray chloritic sandstone inter- } \\
\text { bedded with red, green, and gray silt- } \\
\text { stone and shale. }\end{array}$ & \\
\hline
\end{tabular}

${ }_{2}^{1}$ Lithologic descriptions are based on detailed stratigraphic work by Love $(1947,1956 \mathrm{a}, \mathrm{b})$ and Love and others $(1948,1951)$.

(t) 80 gpm.

${ }^{3}$ May include Morrison Formation (Jurassic), but no Jurassic fossils have been found in this region. 
Hole, pre-Bull Lake glacial drift occurs as isolated remnants high above streams. PreBull Lake drift was recognized on the top of Signal Mountain (Fryxell, 1930), and other scattered remnants may be present elsewhere in the project area.

During the Bull Lake Glaciation, valley glaciers extended from the canyons of the Teton Range onto the floor of Jackson Hole. The glaciers built moraines and outwash plains that are conspicuous features in Jackson Hole south of the project area. A laminated silt bed, which lies 500 feet above the level of Pilgrim Creek (NE $\frac{1}{4} \mathrm{NE}_{\frac{1}{4}}$ sec. 29, T. 46 N., R. 114 W., unsurveyed), is the only deposit of Bull Lake age that has been recognized in the project area. Silt from this bed has a carbon-14 date of about 27,000 years (Love, 1961 , p. 1,753 ; 1956c, p. 149).

Glaciers of the Pinedale Glaciation occupied the same canyons as the Bull Lake glaciers; however, the Pinedale glaciers did not extend as far onto the floor of Jackson Hole. Outwash plains and moraines, many still impounding lakes, have been altered only slightly since Pinedale time. A moraine of Pinedale age impounds Jackson Lake, and an extensive outwash plain lies south of Jackson Lake. Most of the glacial deposits shown on the geologic map (fig. 3) are of Pinedale age, although some unrecognized older glacial deposits probably are present. Marl, which is associated with and possibly is slightly older than the deposits of the Pinedale outwash plain south of Jackson Lake, contains shell material with a carbon-14 date of about 9,000 years (Love, 1956c, p. 150).

The threefold glaciation concept used in studies of Jackson Hole is oversimplified and will undoubtedly be modified in the future. Fryxell (1930) indicated that the Bull Lake Glaciation might have been a time of multiple advances, but he did not attempt to map them. Multiple advances of the Pinedale Glaciation would explain the complex glacial deposition east of Jackson Lake more accurately. In the Wind River Range two Bull Lake advances and at least two Pinedale advances were recognized by Richmond (1948) and Holmes and Moss (1955).

\section{GROUND WATER}

Little ground-water data were available prior to this study. Logs of wells and test holes that were available are given in table 2 .
Table 3 includes records of wells, springs, and test wells, and plate 1 shows the location of wells, test wells, test holes, and springs.

\section{GEOLOGIC UNITS AND THEIR WATER-BEARING POSSIBILITIES}

\section{UNITS OF CRETACEOUS AND TERTIARY AGE}

Little information is available concerning the quantity and quality of ground water in Cretaceous and Tertiary rocks. One well (45-114-19baa) taps the Bivouac Formation of late Pliocene or Pleistocene age, but no other wells are known to tap rocks of possible preQuaternary age. Table 1 gives the general lithologic character of Cretaceous and Tertiary rocks and estimates of their potentials as aquifers. For all formations except the Bivouac, these estimates are based entirely on the lithologic character of the formations and the hydrologic properties of similar formations in other areas.

\section{UNITS OF QUATERNARY AGE}

Most of the deposits of Quaternary age have not been mapped or described in detail. The geologic map (fig. 3) shows the extent of the glacial deposits and the post-Pinedale alluvium. Test drilling during this investigation penetrated thick beds of Quaternary age that underlie surficial glacial and alluvial derosits in many localities (fig. 5). Although some of the deposits of Quaternary age are recogniz able as separate units, most are difficult to differentiate.

\section{ALLUVIUM}

Alluvial gravel, sand, silt, and clay occur in the major stream valleys. These alluvial deposits can be separated into two general age groups: younger alluvium, laid down in post-Pinedale time; and older alluvium, laid down before the end of Pinedale Glaciation.

The younger alluvium is shown on the geologic map (fig. 3). Although the beds generally are thin and only partly saturated, moderate quantities of water are obtained from the thicker saturated sections. The thickest section penetrated by test drilling measured 31 feet (test well 45-114-23ccd).

Older alluvium was penetrated by test drilling at Lizard Point and in Pilgrim Creek valley (fig. 5). It consists of thick permeable 
Table 2. - Logs of wells and test holes

[Stratigraphic interpretations made by the authors]

\begin{tabular}{|c|c|c|c|c|c|}
\hline Material & $\begin{array}{c}\text { Thick- } \\
\text { ness } \\
\text { (feet) }\end{array}$ & $\begin{array}{c}\text { Depth } \\
\text { (feet) }\end{array}$ & Material & $\begin{array}{c}\text { Thick- } \\
\text { ness } \\
\text { (feet) }\end{array}$ & $\begin{array}{c}\text { Depth } \\
\text { (feet) }\end{array}$ \\
\hline
\end{tabular}

45-114-19baa

[Log of well drilled for U.S. Bur. Reclamation. Descriptions are based on driller's log and on sample descriptions by J. D. Love]

\begin{tabular}{|c|c|c|c|c|c|}
\hline 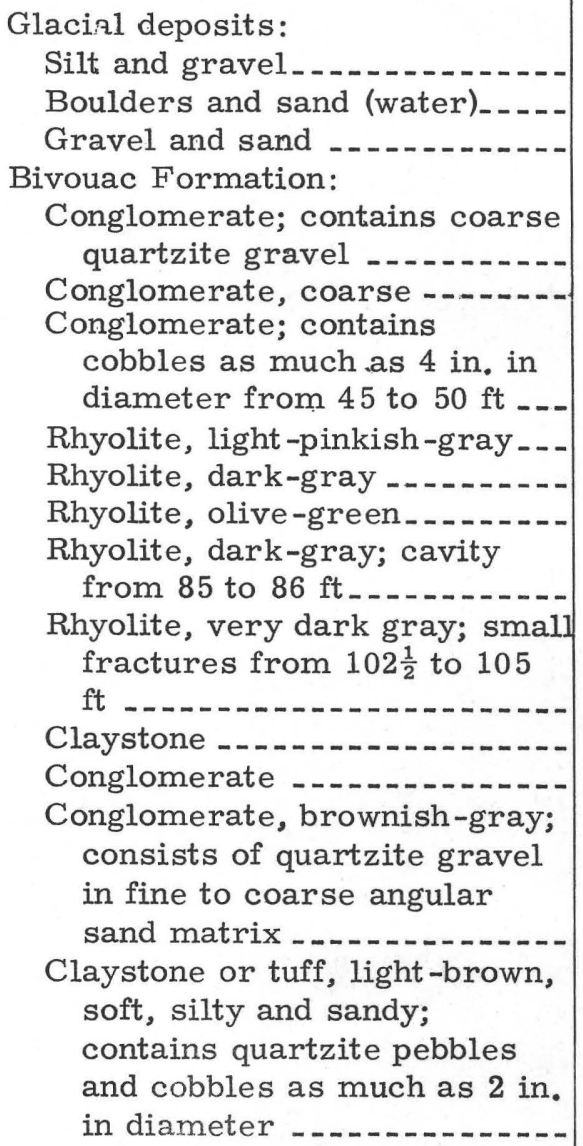 & $\begin{array}{r}20 \\
5 \\
5 \\
10\end{array}$ & $\begin{array}{r}50 \\
55 \\
60 \\
70 \\
102\end{array}$ & 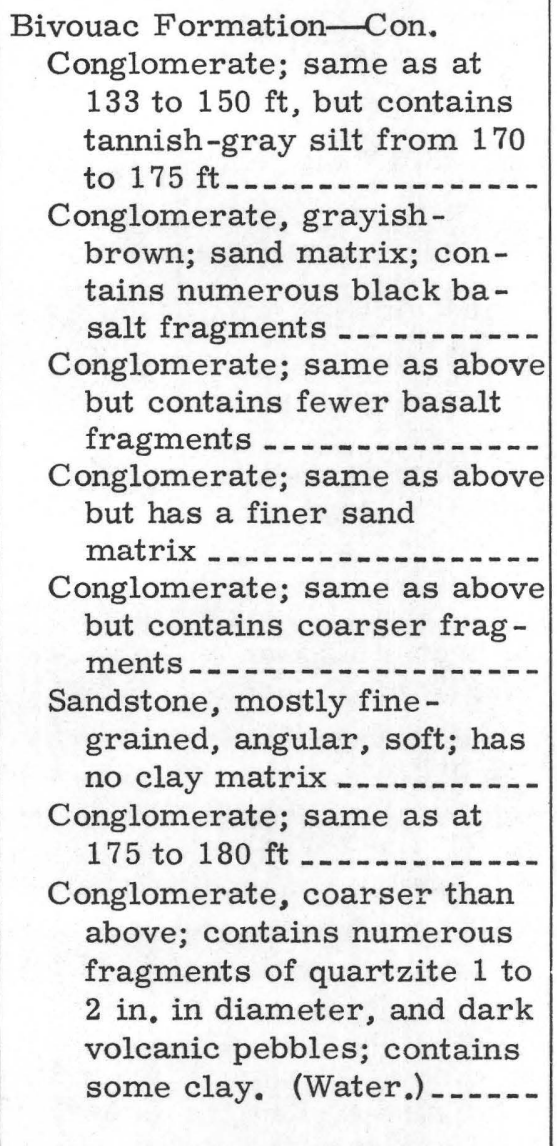 & $\begin{array}{l}3 \\
7\end{array}$ & $\begin{array}{r}205 \\
212\end{array}$ \\
\hline
\end{tabular}

45-114-2 5cdd

[Driller's log of test hole drilled for U.S. Army, Corps of Engineers]

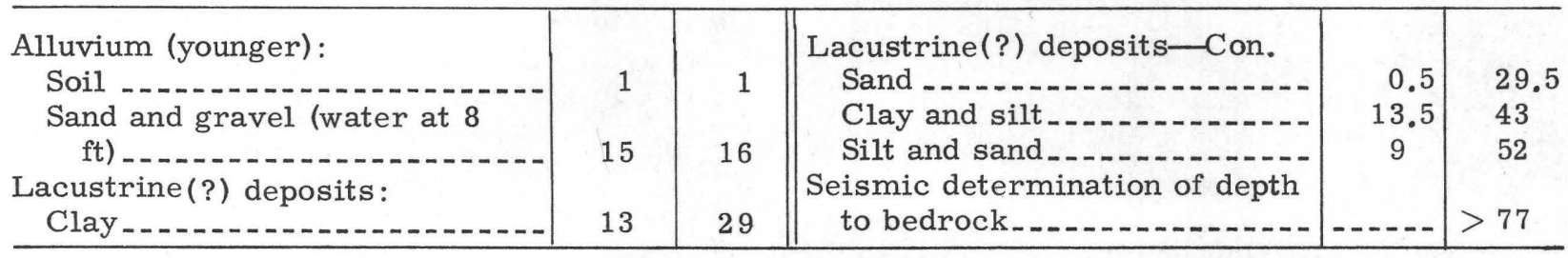


Table 2. - Logs of wells and test holes-Continued

\begin{tabular}{c|c|c||c|c|c}
\hline Material & $\begin{array}{c}\text { Thick- } \\
\text { ness } \\
\text { (feet) }\end{array}$ & $\begin{array}{c}\text { Depth } \\
\text { (feet) }\end{array}$ & Material & $\begin{array}{c}\text { Thick- } \\
\text { ness } \\
\text { (feet) }\end{array}$ & $\begin{array}{c}\text { Depth } \\
\text { (feet) }\end{array}$ \\
\hline
\end{tabular}

45-115-25abdl

[Sample log of test hole drilled by U.S. Geological Survey]

\begin{tabular}{|c|c|c|c|c|c|}
\hline $\begin{array}{l}\text { Deposits filling kettle hole: } \\
\text { Silt, clayey, sandy, yellow } \\
\text { Silt and clay, sandy, tan; con- } \\
\text { tains some gravel } \\
\text { Clay and silt, sandy, light- } \\
\text { grayish-tan.-. } \\
\text { Clay and silt, sandy, light-gray- } \\
\text { ish-tan; contains some gravel }\end{array}$ & 10 & $\begin{array}{l}10 \\
15 \\
20 \\
25\end{array}$ & $\begin{array}{l}\text { Deposits filling kettle } \\
\text { hole-Con. } \\
\text { Silt and clay, sandy, light- } \\
\text { grayish-tan } \\
\text { Glacial deposits: } \\
\text { Boulders (bottom of hole) }\end{array}$ & $\ldots$ & $\begin{array}{l}29 \\
29\end{array}$ \\
\hline
\end{tabular}

45-115-2 5abd2

[Sample log of test hole drilled by U.S. Geological Survey]

Deposits filling kettle hole:

Clay and silt, sandy, tan; contains some gravel

\begin{tabular}{l||l|l|l|l} 
& & $\begin{array}{l}\text { Glacial deposits: } \\
\text { Boulders (bottom of hole) } \ldots . .-\end{array}$ & & 5 \\
\hline
\end{tabular}

$46-115-22 a b d$

[Driller's log of well drilled for A. C. Berol]

\begin{tabular}{|c|c|c|c|c|c|}
\hline $\begin{array}{l}\text { Undifferentiated deposits of } \\
\text { Quaternary age: } \\
\text { Soil and coarse gravel }\end{array}$ & & & $\begin{array}{l}\text { Undifferentiated deposits of } \\
\text { Quaternary age-Con. } \\
\text { Gumbo blue and gravel }\end{array}$ & 10 & 121 \\
\hline $\begin{array}{l}\text { Soil and coarse gravel } \\
\text { Gravel, coarse }\end{array}$ & $\begin{array}{r}4 \\
59\end{array}$ & $\begin{array}{r}4 \\
63\end{array}$ & $\begin{array}{l}\text { Gumbo, blue, and gravel } \\
\text { Sand, brown }\end{array}$ & $\begin{array}{r}10 \\
2\end{array}$ & 123 \\
\hline Sand, brown & 3 & 66 & Gravel, coarse & 8 & 131 \\
\hline Cement gravel & 17 & 83 & Cement gravel & 28 & 159 \\
\hline Gravel, coarse & 24 & 107 & Water gravel & 4 & 163 \\
\hline Water gravel & 4 & 111 & Silt and gravel & 7 & 170 \\
\hline
\end{tabular}

46-115-22add2

[Driller's log of well drilled for A. C. Berol]

\begin{tabular}{|c|c|c|c|c|c|}
\hline $\begin{array}{l}\text { Glacial deposits: } \\
\text { Gravel and boulders }\end{array}$ & 15 & 15 & $\begin{array}{l}\text { Undifferentiated deposits of } \\
\text { Quaternary age-Con. }\end{array}$ & & \\
\hline Undifferentiated deposits of & & & Gravel, coarse & 2 & 99 \\
\hline Quaternary age: & & & Water gravel ...... & 4 & 103 \\
\hline Clay and gravel ... & 5 & 20 & Cement gravel & 7 & 110 \\
\hline Gravel & 10 & 30 & Gravel, coarse & 4 & 114 \\
\hline Gravel, loose & 10 & 40 & Water gravel _.... & 1 & 115 \\
\hline Gravel, tight & 10 & 50 & Cement gravel & 2 & 117 \\
\hline Cement gravel & 5 & 55 & Water gravel & 3 & 120 \\
\hline Cement gravel and boulders & 5 & 60 & Cement gravel & 15 & 135 \\
\hline Gravel, loose (some water).. & 5 & 65 & Cement gravel and boulders .. & 5 & 140 \\
\hline Gravel, coarse, and sand.... & 15 & 80 & Water gravel & 2 & 142 \\
\hline Gravel, coarse & 10 & 90 & Silt and gravel & 2 & 144 \\
\hline Cement gravel & 7 & 97 & Water gravel & 5 & 149 \\
\hline
\end{tabular}


Well or spring No.: See text for description of well-numbering system.

Type of supply: Dr, drilled well; Du, dug well; Sp, spring.

Depth of well: Measured depths are given in feet and tenths of feet below land surface; reported depths are given in feet.

Geologic source (in alphabetical order): Qa, older alluvium;

Qal, younger alluvium; Qg, glacial deposits; Q1, lacustrine deposits; QTb, Bivouac Formation; Qu, undifferentiated rocks of Quaternary age.

Method of lift: C, centrifugal; Cy, cylinder; J, jet;
$\mathrm{S}$, submersible turbine; $\mathrm{T}$, shaft turbine; $(\mathrm{T})$, turbine pump temporarily installed for pumping test wells.

Use of well: D, domestic; O, observation well; P, public supply; $\mathrm{S}$, stock; T, test well.

Depth to water: Measured depths are given in feet and hundredths of feet; reported depths are given in feet.

Remarks: $\mathrm{Ca}$, chemical analysis given in table 6; D, discharge in gallons per minute ( $M$, measured; $R$, reported); L, log of well given in table 2 or graphic log shown in figure 5 .

\begin{tabular}{|c|c|c|c|c|c|c|c|c|c|c|c|c|c|}
\hline $\begin{array}{l}\text { Well or } \\
\text { spring No. }\end{array}$ & Owner or user & 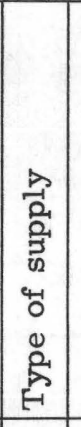 & 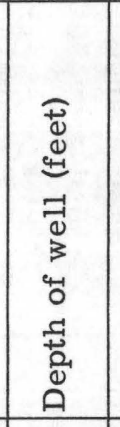 & 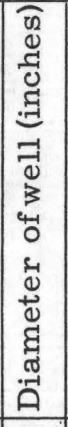 & $\begin{array}{l}0 \\
0 \\
0 \\
0 \\
0 \\
0 \\
0 \\
00 \\
0 \\
0 \\
0 \\
0 \\
0 \\
0\end{array}$ & 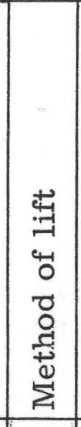 & $\begin{array}{c}\overrightarrow{1} \\
0 \\
3 \\
4 \\
0 \\
0 \\
02 \\
5\end{array}$ & 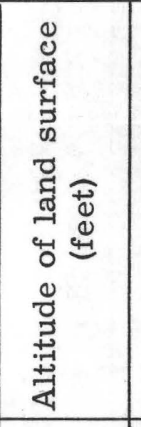 & 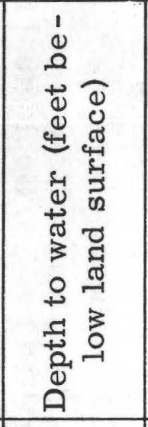 & 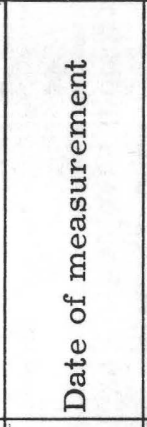 & 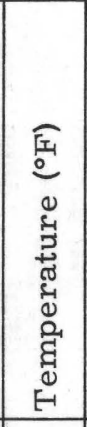 & 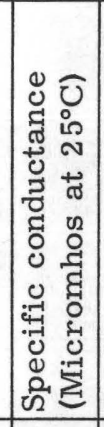 & Remarks \\
\hline $\begin{array}{r}18 \mathrm{dcb}-- \\
19 \mathrm{baa}-- \\
19 \mathrm{bdc}-- \\
23 \mathrm{ccd}-- \\
26 \mathrm{abb} 1 \\
26 \mathrm{abb} 2 \\
26 \mathrm{bab}-- \\
45-115-24 \mathrm{cdd}-- \\
25 \mathrm{bbd}-- \\
25 \mathrm{bca}--\end{array}$ & $\begin{array}{l}\text { Grand Teton Lodge and } \\
\text { Transportation Co } \\
\text { Three Rivers Ranch } \\
\text { U.S. Bur. Public Roads- } \\
\text { Nat. Park Service } \\
\text { Jackson Hole Biological } \\
\text { Research Sta } \\
\text { Grand Teton Lodge and } \\
\text { Transportation Co } \\
\text { U.S. Bur. Reclamation } \\
\text { Nat. Park Service } \\
\text { Moran Post Office } \\
\text { Moran School } \\
\text { Nat. Park Service } \\
\text { Signal Mountain Lodge } \\
\text { Nat. Park Service } \\
\text {. - do do }\end{array}$ & $\left|\begin{array}{c}\mathrm{Dr} \\
\mathrm{Dr} \\
\mathrm{Dr} \\
\mathrm{Dr} \\
\mathrm{Dr} \\
\mathrm{Dr} \\
\hdashline \mathrm{Dr} \\
\mathrm{Dr} \\
\mathrm{Dr}\end{array}\right|$ & $\left|\begin{array}{c}-\cdots \\
12 \\
12 \\
\hdashline 90 \\
450 \\
\\
307 \\
216 \\
89.7 \\
55.0 \\
60 \\
200 \\
\hdashline 160 \\
152.0 \\
205.5\end{array}\right|$ & \begin{tabular}{|r|}
6 \\
6 \\
6 \\
6 \\
8 \\
-- \\
\hdashline- \\
6 \\
6 \\
6
\end{tabular} & $\begin{array}{l}\mathrm{Qu} \\
\mathrm{Qal}(?) \\
\mathrm{Qal}(?) \\
\mathrm{Qu} \\
\mathrm{Qu} \\
\mathrm{Qa}(?) \\
\\
\mathrm{Qa}(?) \\
\mathrm{QTb} \\
\mathrm{Qu} \\
\mathrm{Qal}, \mathrm{Ql}(?) \\
\mathrm{Q1}(?) \\
\mathrm{Ql}(?) \\
\mathrm{Qal}(?) \\
\mathrm{Qu} \\
\mathrm{Qu} \\
\mathrm{Qu}\end{array}$ & \begin{tabular}{|l}
-- \\
$\mathrm{Cy}$ \\
$\mathrm{J}$ \\
--- \\
$-\cdots$ \\
$\mathrm{J}$ \\
\\
$\mathrm{C}$ \\
$\mathrm{J}$ \\
$\mathrm{J}$ \\
$(\mathrm{T})$ \\
$\mathrm{J}$ \\
$\mathrm{J}$ \\
--- \\
$\mathrm{T}$ \\
$(\mathrm{T})$ \\
$(\mathrm{T})$
\end{tabular} & $\begin{array}{l}\mathrm{P} \\
\mathrm{D} \\
\mathrm{D} \\
\mathrm{T} \\
\mathrm{D} \\
\mathrm{P} \\
\mathrm{D} \\
\mathrm{P} \\
\mathrm{T} \\
\mathrm{T}\end{array}$ & 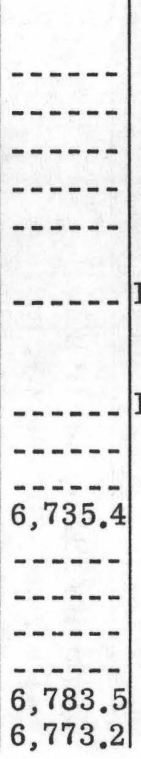 & \begin{tabular}{r}
-6.07 \\
Flowing \\
\\
Flowing \\
70.63 \\
28.35 \\
11.37 \\
\hdashline-10 \\
87.62 \\
42.47
\end{tabular} & $\begin{array}{l}6-14-61 \\
6-14-61 \\
8-17-61\end{array}$ & 43 & \begin{tabular}{r}
-170 \\
-170 \\
220 \\
600 \\
--- \\
\hdashline-1 \\
-230 \\
200
\end{tabular} & $\begin{array}{l}\text { Supply inadequate. } \\
\text { Flow 6M, unpleasant } \\
\text { odor. } \\
\text { D16R, abandoned. } \\
\mathrm{Ca}, \mathrm{L} \text {. } \\
\mathrm{Ca}, \mathrm{D} 30 \mathrm{R} . \\
\mathrm{Ca}, \mathrm{D} 30 \mathrm{M}, \mathrm{L} . \\
\mathrm{Ca} \text {, unpleasant taste. }\end{array}$ \\
\hline
\end{tabular}




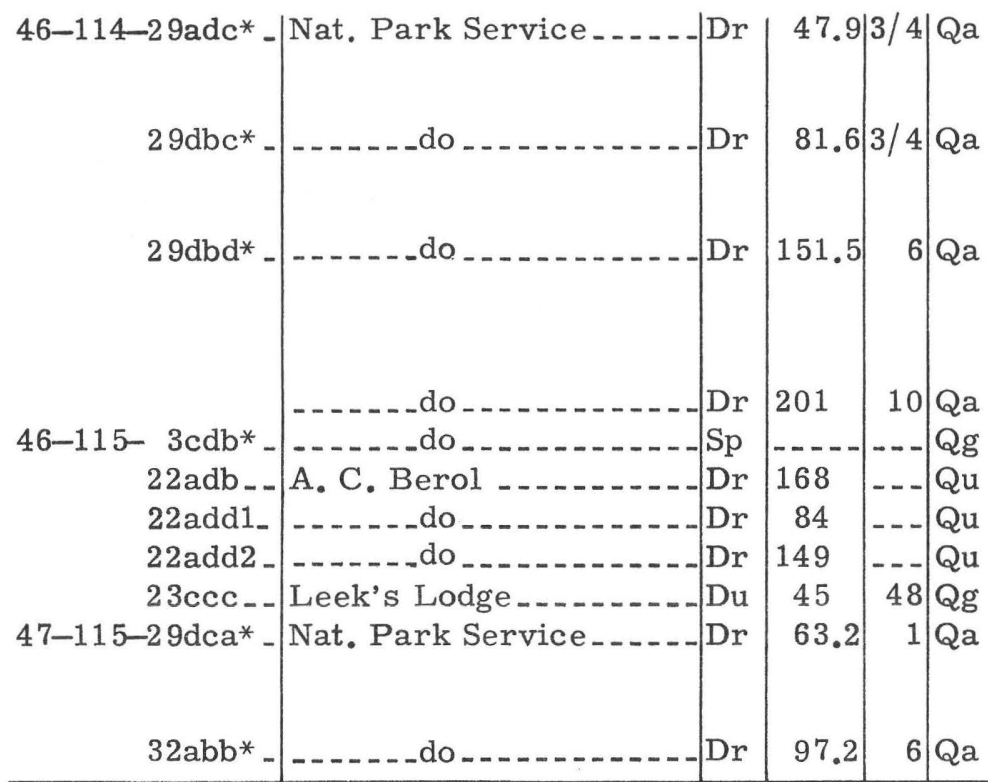

\begin{tabular}{|c|c|c|c|c|c|c|c|}
\hline \multirow[t]{2}{*}{$(\mathrm{T})$} & \multirow[t]{2}{*}{0} & \multirow[t]{2}{*}{$|7,003.0|$} & & & \multirow[t]{2}{*}{40} & \multirow[t]{2}{*}{190} & \multirow{3}{*}{$\begin{array}{l}\text { Former test well: } \\
\text { depth } 97 \mathrm{ft}, 6-i n . \\
\text { casing, Ca, D145M, L. } \\
\text { Former test well: } \\
\text { depth } 100 \mathrm{ft}, 6-\text {-in. } \\
\text { casing, Ca, D135M, L. }\end{array}$} \\
\hline & & & 22.88 & $8-17-61$ & & & \\
\hline$(\mathrm{T})$ & $O$ & $6,986.3$ & 50.50 & $8-17-61$ & 40 & 170 & \\
\hline$(\mathrm{T})$ & $\mathrm{T}$ & $6,982.5$ & 37.98 & $8-17-61$ & 39 & 190 & $\begin{array}{l}\text { Ca, D180M, L; de- } \\
\text { stroyed } 1962 \text {, re- } \\
\text { placed by production } \\
\text { well at same site. } \\
\text { D270M, L; replaces }\end{array}$ \\
\hline$-\cdots$ & $\mathrm{D}$ & $-\ldots-n$ &.----- & $---n$ & 46 & 120 & test well. \\
\hline $\mathrm{S}$ & D & ----- & 75 & & & $-\cdots$ & $\mathrm{Ca}, \mathrm{L}$. \\
\hline-- & $\mathrm{D}$ & $-\ldots-n$ & ------ & 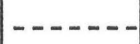 & & -- & Destroyed. \\
\hline & $\mathrm{D}$ & ----- & ------ & & & & $\mathrm{L}$ \\
\hline $\mathrm{J}$ & $\mathrm{P}$ & $\ldots \ldots$ & 32 & & & $\ldots$ & D45R. \\
\hline 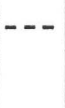 & $\mathrm{O}$ & $6,813.9$ & 39.96 & $8-17-61$ & & & $\begin{array}{l}\text { Former test well: } \\
\text { depth } 83 \mathrm{ft}, 6-i n . \\
\text { casing, bailed } 25 \mathrm{M}, \mathrm{L} \text {. }\end{array}$ \\
\hline त) & $\mathrm{T}$ & $6,795.1$ & 24.12 & $8-17-61$ & 4 & 0 & Ca, D97M, L. \\
\hline
\end{tabular}


beds of sand and gravel that are capable of yielding several hundred gallons of water per minute to wells. More than 130 feet of these deposits was penetrated at test well 46-114$29 \mathrm{dbd}^{*}$ in Pilgrim Creek valley. The thickness and the character, however, probably differ greatly from place to place. These deposits were not penetrated by test drilling in the Buffalo Fork area, but probably occur in most of the major stream valleys.

\section{LACUSTRINE DEPOSITS AT BUFFALO FORK}

Lacustrine deposits overlie bedrock in test holes and wells drilled near the junction of the Snake and Buffalo Fork Rivers. (See fig. 6.) They consist of light-gray very fine sand, silt, and clay, and some beds of coarser sand and gravel. These deposits yield small quantities of water to some wells.

\section{GLACIAL DEPOSITS}

Glacial deposits occur along the east side of Jackson Lake and cover most of the south half of the project area. They consist of un sorted to partly sorted boulders, cobbles, gravel, sand, silt, and clay, and differ greatly in their water-bearing properties. The major deposits of glacial outwash lie south of Signal Mountain and east of Two Ocean Lake. Outwash will yield water to wells where saturated, but most of it has been drained. Most of the glacial deposits, however, are poorly sorted and will generally not yield appreciable amounts of water.

\section{UNDIFFERENTIATED DEPOSITS OF QUATERNARY AGE}

Deposits of Quaternary age that cannot be assigned to specific units without detailed study are called undifferentiated deposits of Quaternary age. These sediments underlie surficial glacial deposits to a depth of several hundred feet along Jackson Lake south of Arizona Creek and yield water to wells at the Berol Ranch, at Signal Mountain Lodge, and at Jackson Lake Campground.

\section{MOVEMENT OF GROUND WATER}

In general, ground water moves southward, following the trend of surface drainage, through Jackson Hole. Water bodies, particularly Jackson Lake and the Snake River, serve as local base levels that control groundwater movement. Differences in permeability of rock units modify this general trend; rocks of low permeability impede ground-water movement and partly isolate some of the aquifers.

Ground-water reservoirs are recharged by direct infiltration of precipitation, by seepage of surface water, and by underflow of ground water from adjacent areas. Only a small part of the precipitation infiltrates to the groundwater reservoirs; most runs off or is evaporated and transpired. Where the surface is very permeable, as in parts of Pilgrim Creek valley and in the outwash deposits south of Signal Mountain, a greater proportion of the precipitation reaches the aquifers than elsewhere.

Water is discharged by evaporation and transpiration, by seeps and springs, by discharge directly to streams and lakes, and by underflow. Only a small amount is discharged by wells.

Ground-water levels reflect rechargedischarge relations of aquifers. Changes in these relations, such as seasonal fluctuations in recharge, cause water levels to rise or decline. Changes in the level of Jackson Lake or the Snake River, by altering local base level, also create changes in recharge-discharge relations. The efficiency of the hydraulic connection between a ground-water reservoir and the lake or river determines the degree to which water levels are affected. Records near Jackson Lake are short and inconclusive but seem to show a slow response of ground-water levels to changes in lake level (fig. 4); this response indicates that the hydraulic connection is rather poor. Water levels in well 45-114-23ccd, in the Buffalo Fork area near the Snake River respond almost immediately to changes in river stage; this response indicates that the hydraulic connection is good (fig. 7).

\section{SPECIAL AREAS OF INVESTIGATIONS}

Special emphasis was given to the investigation of five small areas: The Buffalo Fork area near the junction of the Buffalo Fork and Snake Rivers; the Pilgrim Creek valley area; the Jackson Lake Campground area; the Col ter Bay reservoir area near the storage tank that stores Colter Bay's water supply in the NW $\frac{1}{4}$ sec. 36, T. 46 N., R. 115 W.; and the Lizard Point Campground area. Ground water from these areas was desired by the Park Service. 


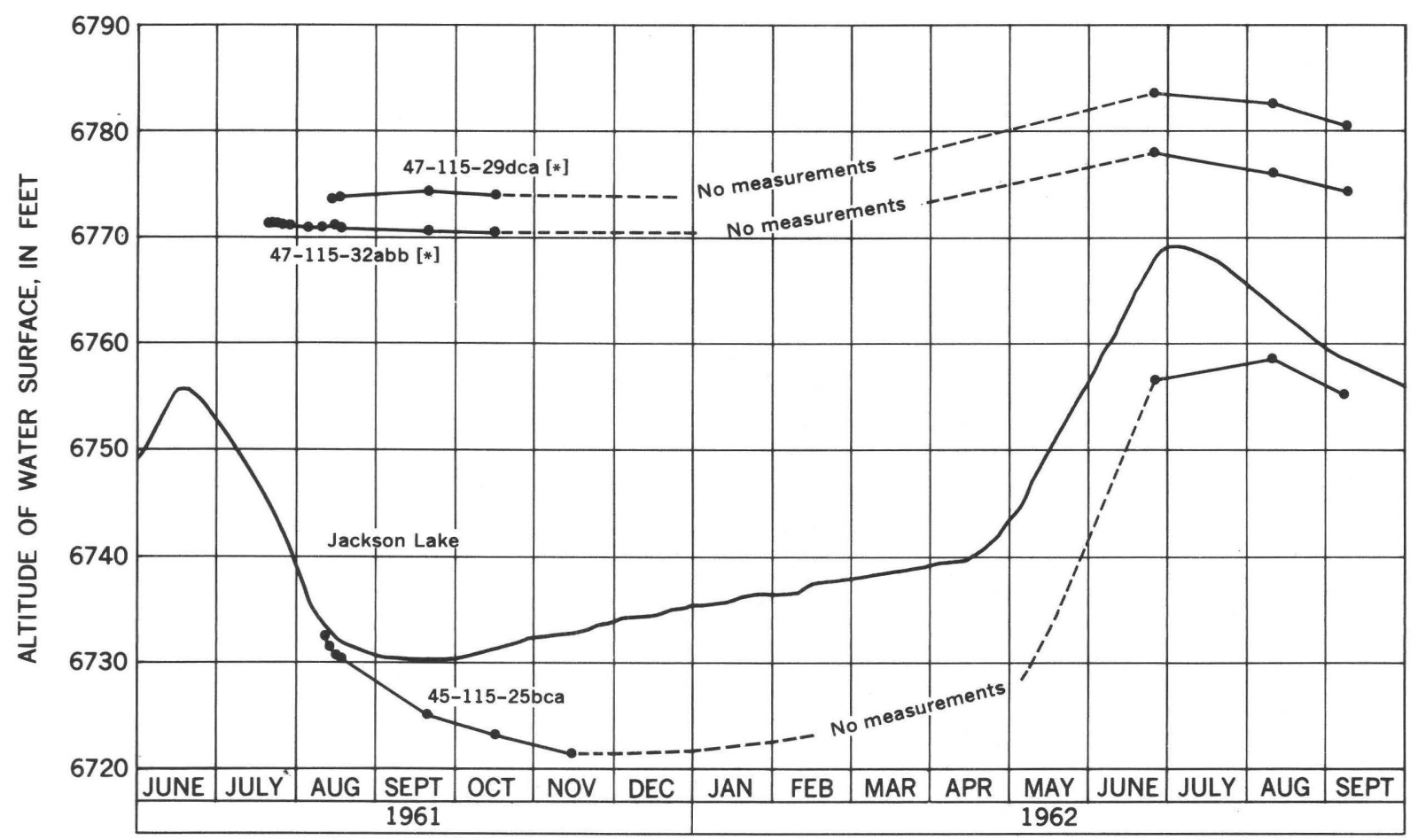

Figure 4. - Stage of Jackson Lake and water levels in nearby wells. Datum is mean sea level. (Lake levels from records of the U.S. Bur. Reclamation.)

Eight test wells and one test hole were drilled in these areas by a private drilling contractor, and three test holes were augered by the Geological Survey in the Buffalo Fork area. Cuttings from the test holes and test wells were examined. Graphic logs of the holes are shown in figure 5 , and locations are shown in plate 1 .

During the drilling of the test wells, brief bailing tests were made as water-bearing materials were penetrated. The quantities of water obtained during the tests are shown in figure 5. These data are useful for comparing the relative permeability of materials, but they do not indicate potential yields of aquifers except in a relative way.

\section{BUFFALO FORK AREA}

\section{GEOHYDROLOGIC SETTING}

Three auger holes and one test well were drilled along the Snake River near the junction with the Buffalo Fork River. Three geologic units were recognizable: (1) Bedrock, (2) lacustrine deposits, and (3) alluvial sand and gravel. The bedrock penetrated during drilling, a bluish-gray soft shale, is part of the Late Cretaceous sequence mapped as lenticular sandstone, shale, and coal and $\mathrm{Ba}-$ con Ridge Sandstone. Overlying the bedrock is a sequence of light-gray very fine to fine sand and silt and some coarser material. J. D. Love (oral commun., 1961) measured and examined in detail about 75 feet of similar deposits exposed in a roadcut a mile east of the test holes and identified them as lacustrine. These lacustrine deposits, of late Quaternary age, are overlain by a thin cover of alluvial sand and gravel at the test-hole sites. (See figs. 5 and 6.)

The Buffalo Fork River valley in the vicinity of the test holes was cut into bedrock to a depth of about 100 feet below the level of the present valley. A lake later covered the area, and thick lacustrine deposits filled the valley. Most of the lake deposits have been removed by erosion, and some have probably been buried by outwash deposits of the Pinedale Glaciation.

During the Pinedale Glaciation, the Snake River was diverted from the western part of Jackson Hole to its present course east of Signal Mountain. The river has cut a narrow passage between the Pacific Creek and Buffalo 


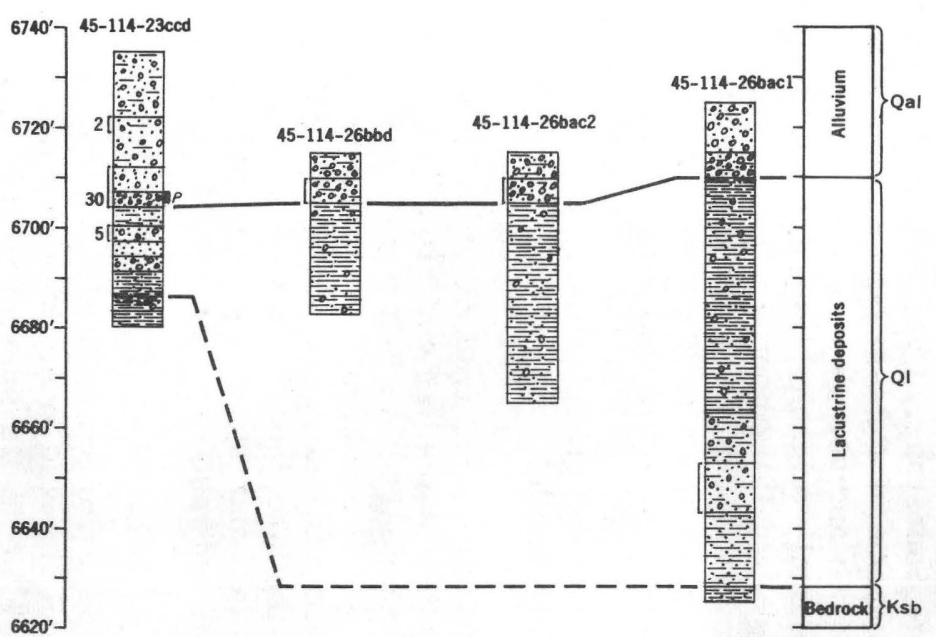

Buffalo Fork area

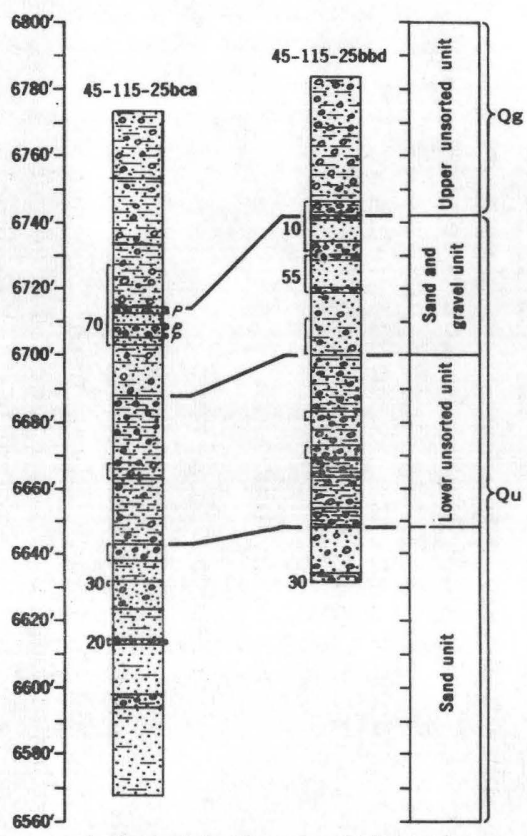

Jackson Lake Campground area

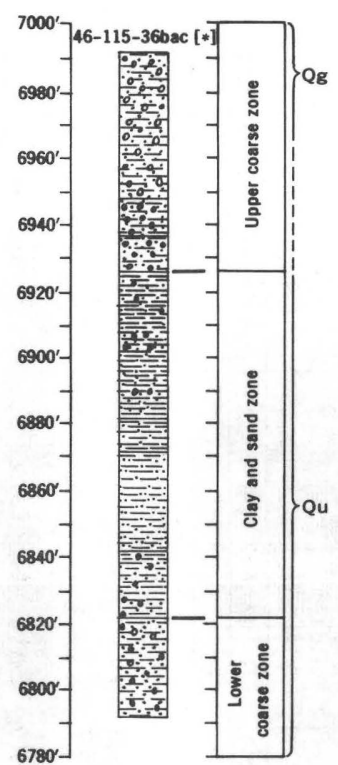

Colter Bay reservoir area

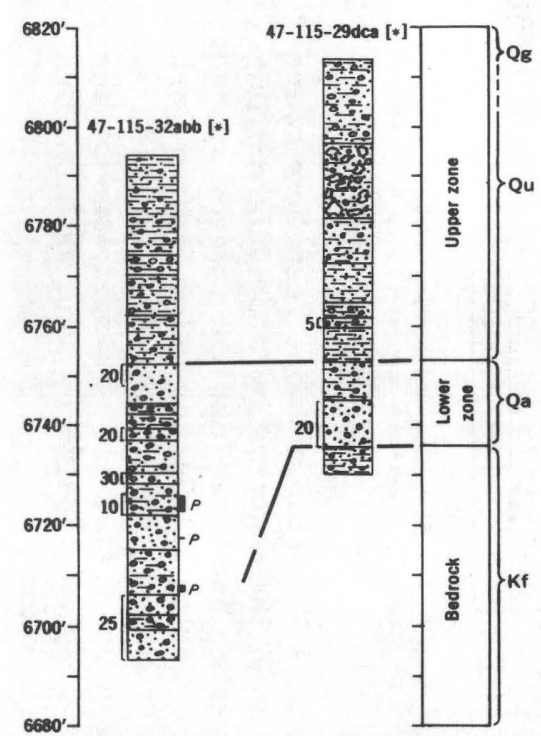

Lizard Point Campground area

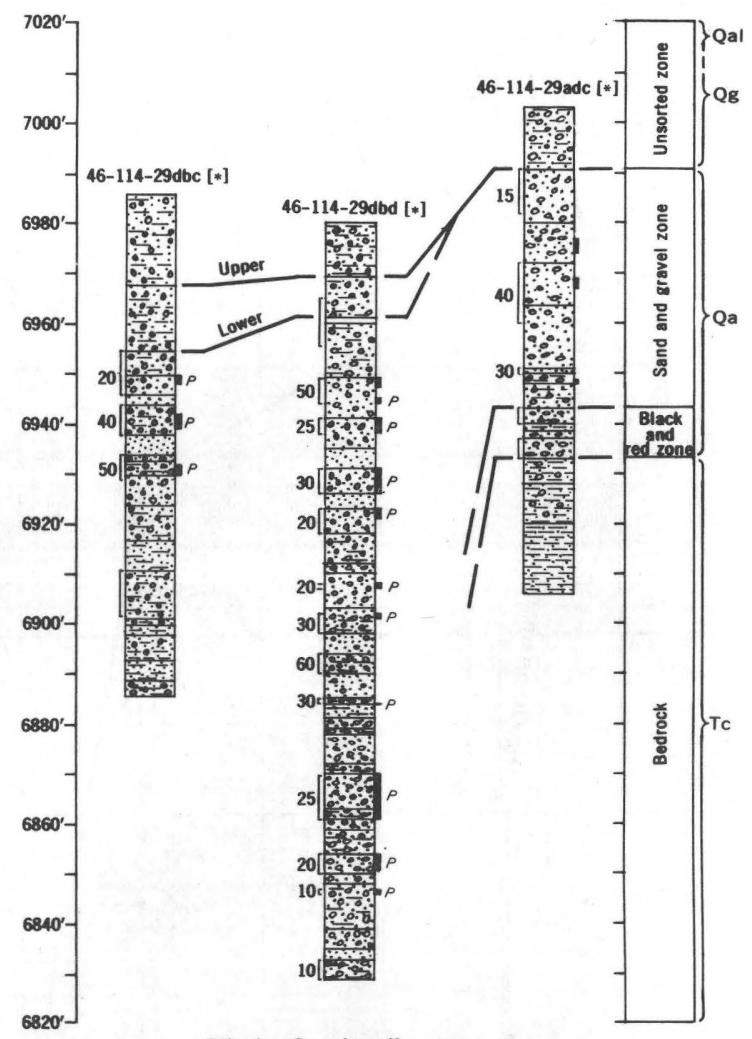

Pilgrim Creek valley area EXPLANATION

$$
20 \text { [ }
$$

Bracket indicates strate that rielded noticable amounts of water during drilling. Numbers show the quantity during brief bailing tests mede during drilling

I $p$
Perforated interval in test well

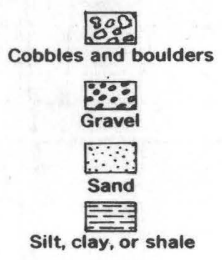

Datum is mean sea level

Note: symbols may be combined

Qal, younger alluvium; Qa, older alluvium; Qg, glacial deposits; QI, lacustrine deposits at Buffalo Fork; Qu, undifferentiated deposits of and coal sequence, and Bacon Ridge Sandstone; and Kf, Frontier Formation 


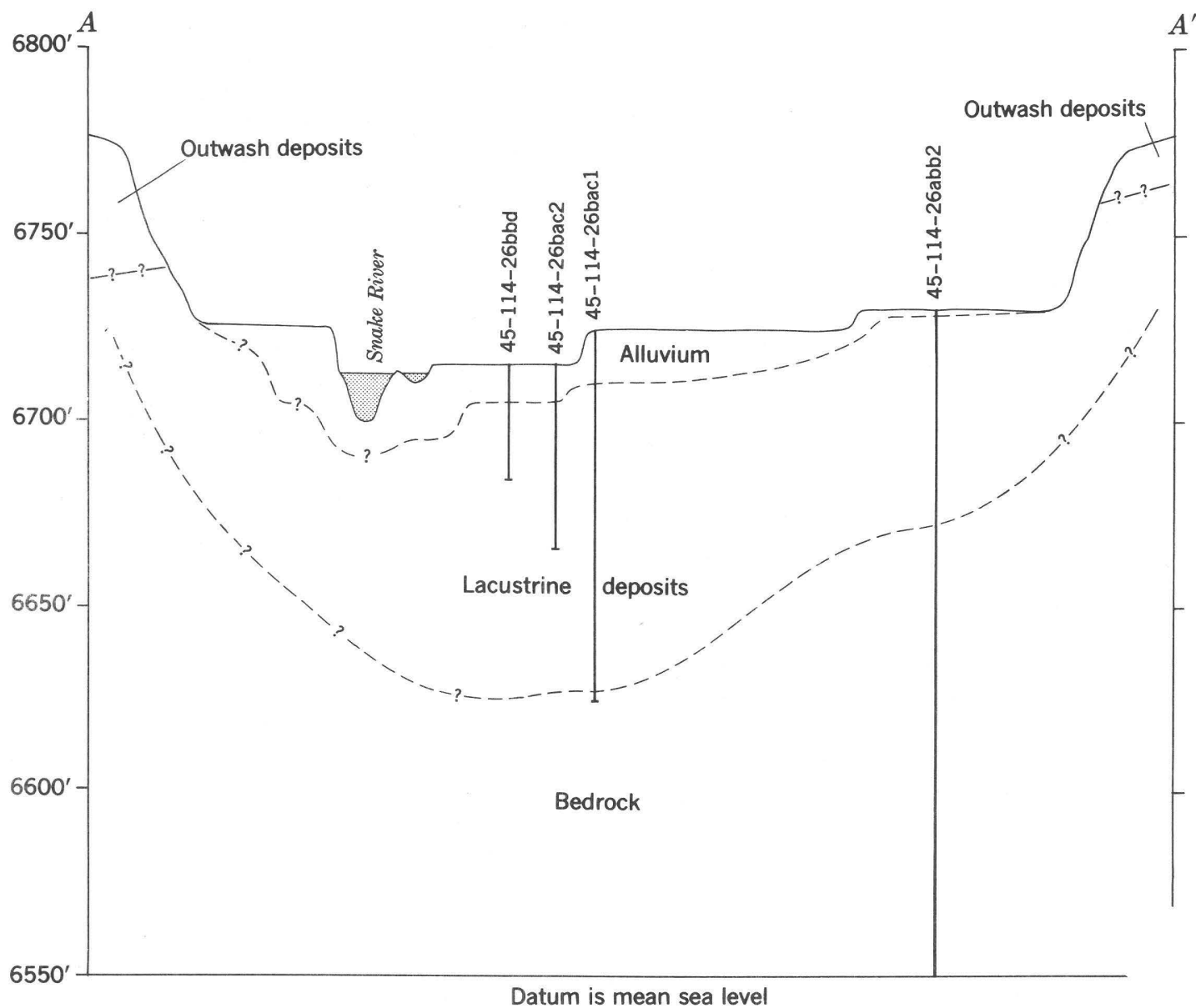

Figure 6. -Diagrammatic section showing the probable relations of alluvium, lacustrine deposits, and bedrock near the juaction of the Snake and Buffalo Fork Rivers. (Location of section shown on pl.1.)

Fork River valleys. Three main terraces, as well as several discontinuous terraces, are recognizable in this short reach. The highest terrace is about 60 feet above the Snake River and is associated with the Pinedale outwash plain. The middle terrace is about 15 feet above the river, and the lowest terrace about 10 feet. The flood plain of the Snake River is narrow in the vicinity of test well 45-114-23 ced but becomes wider downstream.

The alluvium is the most permeable aquifer in the Buffalo Fork area, but it is mostly thin. The thickest alluvium known in the area is 31 feet at test well 45-114-23ccd, which is about 70 feet east of the Snake River on the 10-foot terrace. Auger hole 45-114-26bac1, which is a quarter of a mile downstream on the 10-foot terrace, penetrated 15 feet of alluvium that is almost entirely above the water table. Auger holes 45-114-26bac2 and -26bbd, which are on the flood plain, penetrated only a few feet of saturated alluvium.
A few feet of permeable lacustrine deposits were penetrated by test well 45-114-23ccd and auger hole 45-114-26bac 1 , but most are of low permeability. Two screened wells on the 15-foot terrace about a quarter of a mile east of the auger holes yield small quantities of water from lacustrine(?) sand deposits. According to the driller, both wells penetrated fine (lacustrine?) sand to a depth of about 60 feet. Well 45-114-26abb1 bottomed in clay (bedrock?) at 60 feet, and well 45-114-26abb2 penetrated clay (bedrock?) to a depth of 200 feet. No water was noted below 60 feet.

\section{MOVEMENT OF GROUND WATER}

The Snake River is the major source of recharge to the alluvial and lacustrine deposits in the vicinity of test well 45-114-23ccd. The river and the alluvium are hydraulically connected, and the water table in the alluvium relates closely to the river stage (fig. 7). The lacustrine deposits are generally of low 
permeability, and water moves much slower through them than through the permeable alluvial deposits. Some water is interchanged between the two aquifers and thus, indirectly, between the river and the lacustrine deposits.

\section{PILGRIM CREEK VALLEY AREA}

\section{GEOHYDROLOGIC SETTING}

Three test wells were drilled in the Pilgrim Creek valley about 3 miles north of Jackson Lake Lodge. To conserve drilling funds, the contracting officer for the Park Service stopped the drilling of two of the test wells before bedrock was reached. The third (46114-29adc*) penetrated tuffaceous light-gray to white claystone and gray clayey sandstone of the Colter Formation that contained abundant black and red basalt and andesite grains. Overlying the bedrock was a zone of mostly well-sorted black and red sand and gravel derived from the Colter Formation. This distinctive zone was not penetrated in other test wells. Most of the unconsolidated deposits can be grouped into a sand and gravel zone (fig. 5), which consists of poorly to wellsorted sand and gravel containing a little silt and clay. Unsorted deposits ranging from clay to cobbles overlie the sand and gravel. The lower part of this unsorted zone at test wells 46-114-29dbc* and $-29 \mathrm{dbd}^{*}$ contained no cobbles and less coarse gravel than the upper part. (See fig. 5.)

The forks of Pilgrim Creek flow on bedrock a short distance above their junction, but below this junction a thick layer of sediments overlies the bedrock. Before the end of Pinedale Glaciation, Pilgrim Creek valley had been cut and refilled nearly to its present level; the refilling partly buried drainage divides in the lower reaches. Since Pinedale time, glacial deposits, predominantly outwash, which were added to the valley fill, have been partly reworked.

Test drilling penetrated the coarse permeable deposits near the junction of the forks of Pilgrim Creek. Test well 46-114-29adc* is 500 feet downstream from the junction and 50 feet west of the high-water bank. Test wells

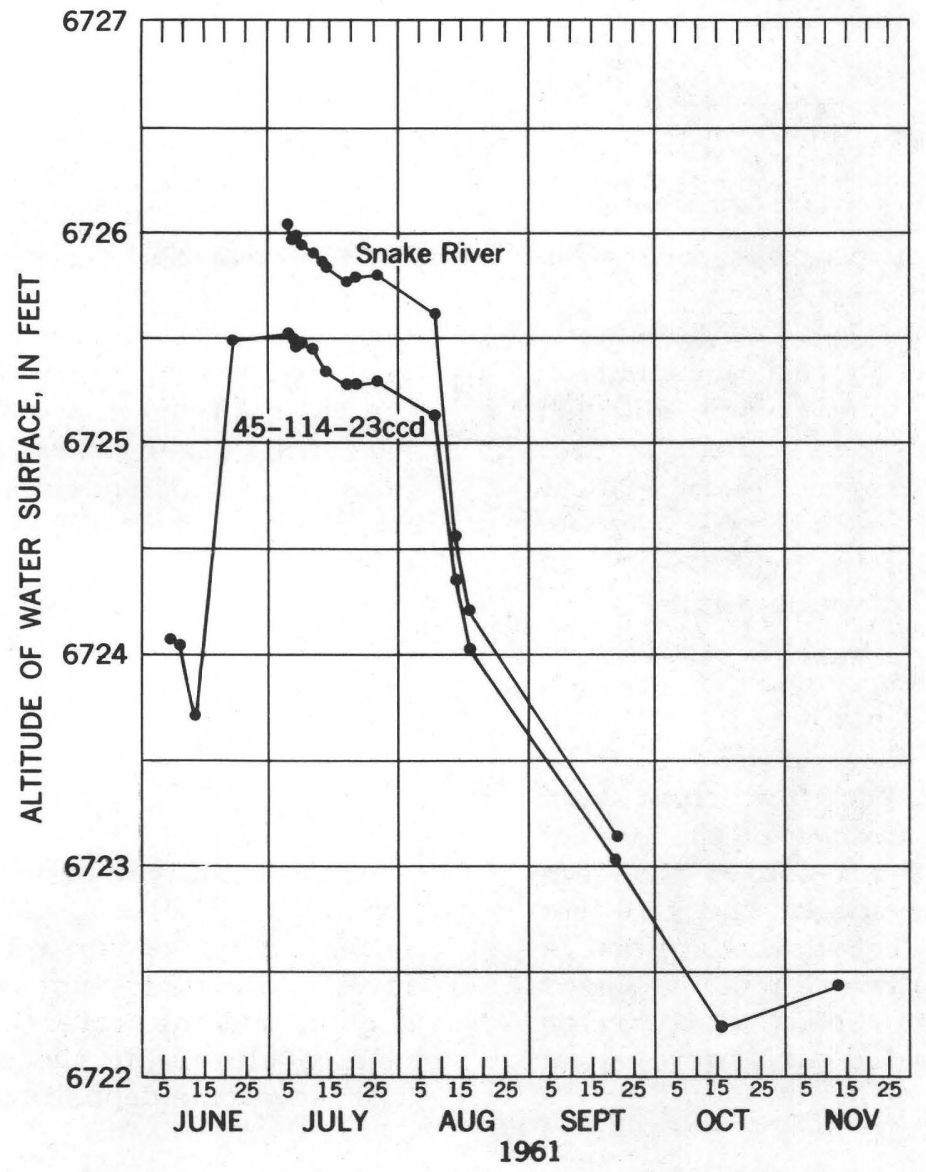

Figure 7. -Relation of the water level in well $45-114-23 \mathrm{ccd}$ to the stage of the Snake River near the well. Datum is mean sea level. 


\begin{tabular}{|c|c|c|}
\hline Material & $\begin{array}{c}\text { Thick- } \\
\text { ness }\end{array}$ & Depth \\
\hline $\begin{array}{l}\text { Production well } \\
\text { [Upper materials are shown } \\
\text { of adjacent test well } 46-11 \\
\text { Total depth of test well wa }\end{array}$ & $\begin{array}{l}\log \\
\text { on graph } \\
-29 \mathrm{dbd}^{*} \\
151.5 \mathrm{ft}]\end{array}$ & $\begin{array}{l}\text { ic } \log \\
\text { (fig. 5). }\end{array}$ \\
\hline $\begin{array}{l}\text { Fine and coarse sand, pea } \\
\text { gravel, and silt } \\
\text { Fine and coarse sand and } \\
\text { pea gravel } \\
\text { Gray quicksand } \\
\text { Gray quicksand and gravel }\end{array}$ & $\begin{array}{r}15 \\
20 \\
7 \\
9\end{array}$ & $\begin{array}{l}165 \\
185 \\
192 \\
201\end{array}$ \\
\hline
\end{tabular}

46-114-2 9dbd* and $-29 \mathrm{dbc}^{*}$ are about $0.4 \mathrm{mile}$ farther downstream and 200 and 700 feet, respectively, west of the high-water bank. No other wells are known in the valley. Two flowing wells east of Jackson Lake Dam probably penetrate deposits similar to those in the lower part of the Pilgrim Creek valley. The wells (45-114-17cac and $-18 \mathrm{dcb})$ reportedly penetrate clay and fine sand to depths of 450 and 307 feet, respectively, but written logs are not available.

In the fall of 1962, after completion of the test drilling and fieldwork for the study, a production well was drilled a few feet from test well $46-114-29 \mathrm{dbd}^{*}$, and the test well was destroyed. The well was drilled to a depth of 201 feet, about 50 feet deeper than the test well. The driller's log of that part of the well below 150 feet is shown above.

\section{MOVEMENT OF GROUND WATER}

The unsorted zone that underlies the surface of the valley in the vicinity of the test wells is permeable and adsorbs water quickly. The discharge of 130 gpm from test well 46114-29dbc* during the 24-hour pumping test seeped into the ground within 150 feet of the well. (See section on "Results of pumping tests.") On the west side of the valley about a mile northeast of the highway, a small intermittent stream enters the valley. All the water from this stream seeps into the valleyfill deposits.

Most of the recharge to the aquifer is seepage from Pilgrim Creek. On June 17, 1960, flow of the creek was $197 \mathrm{cfs}$ (cubic feet per second) at a point 4,500 feet downstream from the junction of the forks of Pilgrim Creek, and was $176 \mathrm{cfs}$ at a point about $2 \frac{1}{2}$ miles downstream from the junction and 300 feet downstream from the old highway bridge. These measurements indicate a reduction in flow of $21 \mathrm{cfs}$, or nearly 14 million gallons per day, in this reach. The amount of water evaporated and transpired is unknown but probably is small compared with the amount that seeps into the aquifer.

Recharge to the aquifer from Pilgrim Creek varies considerably through the year. The flow was measured during the season of high flow, but the stream was not at its highest level. Measurements at other times of the year would show a wide variation. Above the junction of the forks the flow is perennial, but in the late summer of dry years, the flow disappears between the junction and the old highway bridge.

In the lower part of the valley, below the old highway bridge, the situation changes; the water table intersects the land surface and ground water discharges into Pilgrim Creek, other small streams, and marshes. The principal reason for the change is probably a decrease in permeability, which retards the flow of ground water. In the lower valley, surface deposits are composed of fine materials of low permeability, and most of the valley fill is probably less permeable than are deposits in the upper valley.

Water-level fluctuations of as much as 36 feet were measured in the test wells during this study (table 4). Because changes in level mainly reflect changes in recharge, an even greater range in water level should be expected over a period of wet and dry years.

\section{JACKSON LAKE CAMPGROUND AREA}

\section{GEOHYDROLOGIC SETTING}

Two test wells were drilled west of Signal Mountain at the south edge of Jackson Lake Campground. The first test well was drilled about 150 feet east of Jackson Lake, the second was drilled about 150 feet southwest of the first and about 70 feet east of the lake. The wells penetrated four distinct units: (1) An upper unsorted unit, (2) a sand and gravel unit, (3) a lower unsorted unit, and (4) a sand unit. The sand and the sand and gravel units yield appreciable quantities of water. They are separated by poorly permeable unsorted deposits and constitute two aquifers. (See fig. 5.) 
Table 4.-Depths to water (feet below land surface) in observation wells in the Pilgrim Creek valley

\begin{tabular}{|c|c|c|c|c|}
\hline \multicolumn{2}{|c|}{ Date } & $\begin{array}{l}46-114- \\
29 \mathrm{adc}^{*}\end{array}$ & $\begin{array}{l}46-114- \\
29 \mathrm{dbc}^{*}\end{array}$ & $\begin{array}{l}46-114- \\
29 \mathrm{dbd}^{*}\end{array}$ \\
\hline \multicolumn{2}{|c|}{1961} & & & \\
\hline \multirow[t]{9}{*}{ June } & 22 & 5.25 & - & --- \\
\hline & $23 \ldots$ & 5.36 & $\ldots \ldots$ & 17.17 \\
\hline & $24 \ldots$ & 5.46 & 29.04 & $\ldots \ldots$ \\
\hline & $25 \ldots$ & 5.51 & 29.14 & 17.54 \\
\hline & $26 \ldots$ & 5.61 & 29.20 & 17.61 \\
\hline & $27 \ldots$ & 5.68 & 28.99 & 17.99 \\
\hline & $28 \ldots$ & 5.76 & $\ldots \ldots$ & 18.15 \\
\hline & $29 \ldots$ & 5.83 & 29.65 & 18.16 \\
\hline & $30 \ldots$ & 6.20 & 29.83 & 18.31 \\
\hline \multirow[t]{12}{*}{ July } & $1 \ldots$ & $\ldots \ldots$ & 29.99 & 18.44 \\
\hline & $2 \ldots$ & 6.84 & 30.11 & 18.57 \\
\hline & $5 \ldots$ & 7.57 & 30.60 & 19.33 \\
\hline & $6 \ldots$ & 8.15 & 30.97 & 19.95 \\
\hline & $7 \ldots \ldots$ & 8.80 & 31.57 & 20.73 \\
\hline & $8 \ldots$ & 9.10 & 31.97 & 21.17 \\
\hline & $11 \ldots$ & 10.18 & 33.68 & 22.96 \\
\hline & $13 \ldots$ & $=\cdots$ & 34.88 & 24.15 \\
\hline & $14 \ldots$ & ${ }^{1} 14.70$ & $\ldots \ldots$ & 24.88 \\
\hline & $19 \ldots$ & 15.63 & $\ldots \ldots$ & 27.45 \\
\hline & $21 \ldots$ & 15.17 & $\ldots \ldots$ & 28.34 \\
\hline & $28 \ldots$ & 17.79 & ---- & $\ldots \ldots$ \\
\hline \multirow[t]{4}{*}{ August } & $2 \ldots$ & 19.39 & ${ }^{1} 46.56$ & - \\
\hline & $4 \ldots$ & 19.84 & $\ldots \ldots$ & 33.75 \\
\hline & $12 \ldots$ & 21.47 & 48.90 & 35.31 \\
\hline & $17 \ldots$ & 22.88 & 50.50 & 37.98 \\
\hline September & $r 21 \ldots$ & 33.00 & 59.86 & 47.70 \\
\hline October & $16 \ldots$ & 39.30 & 63.34 & 50.18 \\
\hline \multirow[t]{4}{*}{ November } & $14 \ldots$ & 23.28 & 48.89 & 30.18 \\
\hline & $15 \ldots$ & 23.48 & 48.18 & 29.27 \\
\hline & $16 \ldots$ & 23.36 & 47.66 & 28.84 \\
\hline & $17 \ldots$ & 23.27 & 47.50 & 29.36 \\
\hline \multicolumn{2}{|c|}{1962} & & & \\
\hline June & $25 \ldots$ & 12.68 & 27.70 & 14.29 \\
\hline August & $10 \ldots$ & 23.17 & 39.36 & 26.44 \\
\hline September & r $8 \ldots$ & 33.05 & 50.98 & 38.76 \\
\hline
\end{tabular}

${ }^{1}$ Well construction changed. (See table 3.)

More data will be required before the deposits can be properly correlated, but all presumably are of Quaternaryage. The unsorted surface deposits are Pinedale drift and part of the moraine bounding Jackson Lake. The lower unsorted unit is probably glacial drift and represents either an earlier phase of the Pinedale Glaciation or the Bull Lake Glaciation. The areal extent of the aquifers and their relations to rocks in adjacent areas are unknown.
Well 45-115-24cdd, about 0.4 mile north is reported to be 160 feet deep. No log is available. Water analyses show that the water from this well is similar to water from the sand and gravel unit penetrated by the test wells.

\section{MOVEMENT OF GROUND WATER}

The water level in test well 45-115-25bca, which receives most of its water from the sand and gravel unit, seems to follow, with a notable lag, changes in the level of Jackson Lake and is generally lower than the lake level. Only a few water-level measurements have been made (fig. 4), and additional data would be required before reliable conclusions could be drawn, but Jackson Lake seems to be a major source of recharge to the sand and gravel unit.

The rate of water movement between the sand and the sand and gravel units is probably low. The water level in the sand and gravel unit is about 30 feet higher than that in the sand unit.

\section{COLTER BAY RESERVOIR AREA}

One test hole (46-115-36bac*) was drilled about 200 feet southeast of the concrete tank that stores Colter Bay's water supply. The hole was on a bench on a hillside covered with glacial drift and was about 130 feet higher than the adjacent valleys. This area was tested at the request of the Park Service be cause of the convenience of the location to the reservoir, rather than for geologic advisability.

The hole penetrated unsorted cobbles, gravel, sand, silt, and clay from 0 to 66 feet. Morainal topography at the surface indicates that at least the upper part is glacial; more than one stage of glaciation may be represented. The material from 66 to 170 feet consists of sandy yellowish-green and yellow clay, sandy brown clay, clayey sand, and gravelly clay. The material from 170 to 200 feet consists of unsorted clay, silt, sand, gravel, and cobbles. The deposits could not be correlated with known units, but all presumablyare of Quaternary age.

No water was found, and drilling was stopped at 200 feet. Most of the material penetrated was of low permeability because of poor sorting and abundance of clay and silt. 
Saturated material may not have been penetrated; the test-hole site is higher than the adjacent valleys, and the material tested may have been drained.

\section{LIZARD POINT CAMPGROUND AREA}

\section{GEOHYDROLOGIC SETTING}

Two test wells were drilled in the Lizard Point Campground at the north end of Jackson Lake. The bedrock penetrated in test well 47-115-32abb* consists of greenish-gray soft shaly sandstone, containing some very fine gravel; it is probably part of the Frontier Formation of Late Cretaceous age. The unconsolidated deposits overlying the bedrock can be divided into two zones. The waterbearing lower zone consists of poorly sorted to well-sorted sand and gravel, containing a little silt and clay. The poorly permeable upper zone consists of unsorted to poorly sorted deposits ranging from clay to boulders. (See fig. 5.)

A veneer of glacial material of Pinedale age covers the tip of Lizard Point and overlies more than 100 feet of valley fill near test well 47-115-32abb*. Deep cuts scoured by pre-Bull Lake ice sheets descend below the valley fill in the vicinity, and test well 47115-29dca* penetrates sediments deposited in one of these cuts.

\section{MOVEMENT OF GROUND WATER}

Recharge to the aquifer penetrated by the Lizard Point test wells may be either by semiconfined underflow from upstream reaches of the Snake River, from precipitation in the adjacent highlands, or both. The hydraulic head in the aquifer is above the lake, and water levels in the test wells decline very little when the lake is at low levels (fig. 4). Deposits overlying the main aquifer, although at least partly saturated, are relatively impermeable and act as a semiconfining bed that prevents rapid drainage. Springs occur at and below the line of high lake stage along Lizard Point. They discharge from more permeable zones in the deposits overlying the main aquifer, and most continue to flow even when the lake remains at low levels for long periods.

\section{RESULTS OF PUMPING TESTS}

Seven of the test wells were pumped for 24 hours each to determine yields and to evaluate the aquifers. As observation wells were not available, water levels were measured in the pumped wells during pumping and recovery. The drawdown and recovery determined during six of the tests are shown on graphs in figure 8; because of mechanical difficulties, the results of the seventh test (well 45-115$25 \mathrm{bbd}$ ) were questionable and are not shown. The discharge of water from the wells, which could not be closely regulated, was measured at irregular intervals during the tests. Graphs of the discharge are shown with the drawdown curves to show the influence of changes in discharge.

In most of the test wells, the entrance area through which water could move from the aquifers into the wells was small. The wells were drilled by cable tools, and casing was lowered as drilling progressed. After the well was bottomed, the casing was perforated with quarter-inch slots opposite the coarser grained beds only.

Specific capacity-the yield in gallons per minute per foot of drawdown - of the test wells was determined from the pumping-test data given in table 5. It was computed for the longest period of pumping in which the discharge was steady and the increase in drawdown small. Because specific capacity is directly related to the length of perforated casing, other factors being equal, this length is also shown on table 5 .

A comparison of specific capacity of wells can be used to estimate the relative efficiency of wells and the relative permeability of aquifers. Specific capacity varies mainly with well construction and development and also with aquifer characteristics; it varies to a much smaller degree with rate and duration of pumping.

\section{BUFFALO FORK TEST}

A yield of about 40 gpm was desired by the Park Service for possible additional facilities to be constructed in the Buffalo Fork area, but $40 \mathrm{gpm}$ probably cannot be sustained by test well 45-114-23ccd. The well was pumped at various rates for short periods before beginning the 24-hour pumping test. It was pumped successfully for a short time at 43 gpm, but when the rate was increased to 50 gpm, it partly filled with sand and silt. After additional cleaning and development, the well was pumped successfully for 24 hours at an average of $30 \mathrm{gpm}$. Because of the danger of 


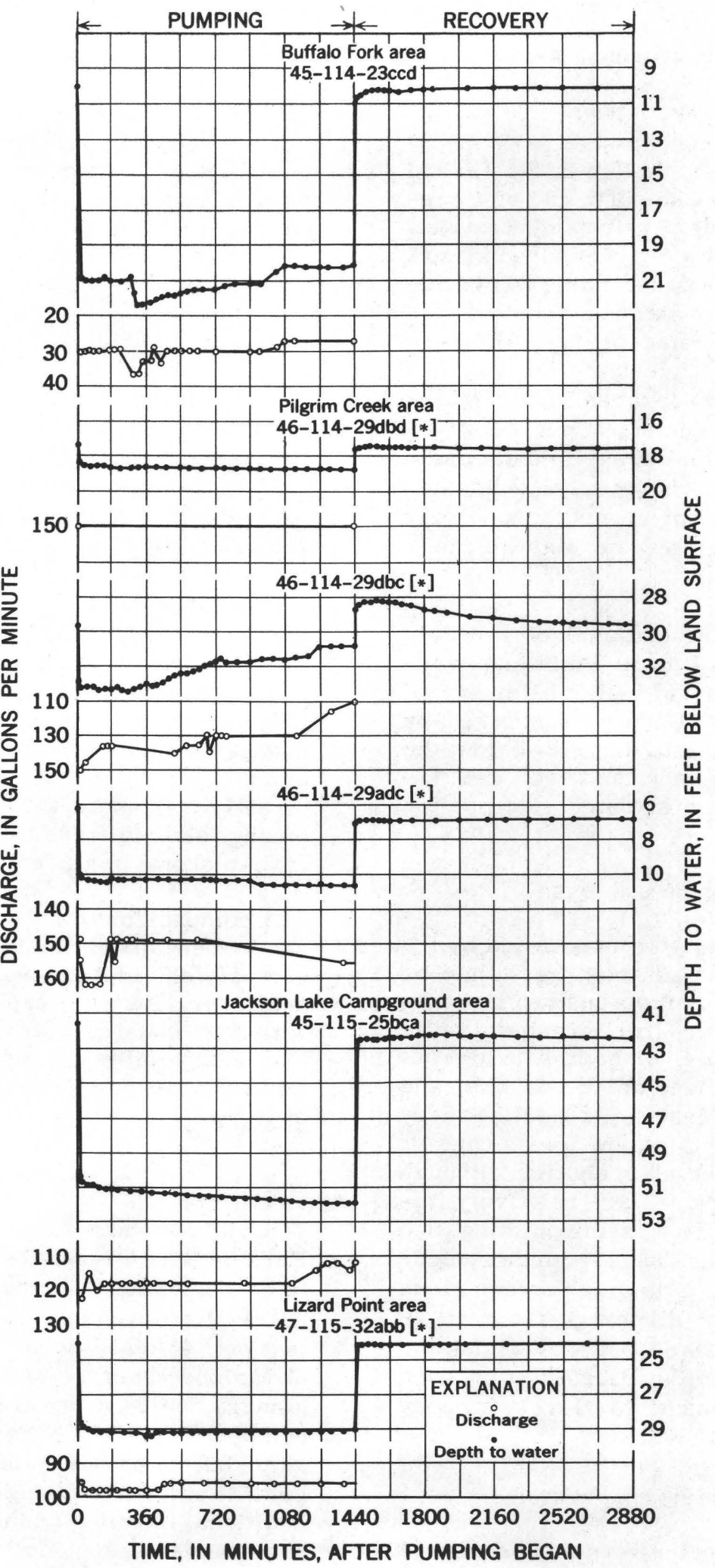

Figure 8. -Water-level and discharge fluctuations of test wells during pumping and recovery tests. 
Table 5.- Specific capacity of test wells

\begin{tabular}{|c|c|c|c|c|c|}
\hline Well & $\begin{array}{l}\text { Specific ca- } \\
\text { pacity (gal- } \\
\text { lons per min- } \\
\text { ute per foot } \\
\text { of drawdown) }\end{array}$ & $\begin{array}{l}\text { Discharge } \\
\text { (gallons per } \\
\text { minute) }\end{array}$ & $\begin{array}{c}\text { Drawdown } \\
\text { (feet) }\end{array}$ & $\begin{array}{c}\text { Time (min- } \\
\text { utes after } \\
\text { pumping } \\
\text { began) }\end{array}$ & $\begin{array}{l}\text { Length of } \\
\text { perforated } \\
\text { casing (feet) }\end{array}$ \\
\hline $45-114-23 \mathrm{ccd} \ldots$ & 2.7 & 30 & 11.23 & 900 & 2 \\
\hline 45-115-2 5bbd_... & .43 & 12.5 & 29.21 & 50 & ${ }^{1} 0$ \\
\hline $25 \mathrm{bca} \ldots$ & 10 & 118 & 11.16 & 1,110 & $41 / 2$ \\
\hline $46-114-29 a^{2}{ }^{*} \ldots$ & 35 & 155 & 4.43 & 1,380 & 6 \\
\hline $29 \mathrm{dbc}^{*} \ldots$ & 37 & 135 & 3.62 & 180 & 7 \\
\hline $29 \mathrm{dbd}^{*} \ldots$ & 100 & 150 & 1.47 & 1,440 & $281 / 3$ \\
\hline $47-115-32 a b b * \ldots$ & 19 & 96 . & 5.06 & 1,020 & $41 / 3$ \\
\hline
\end{tabular}

1 Water entered well through bottom of casing; no open hole below casing.

pumping sand and silt, the discharge should probably be kept below $30 \mathrm{gpm}$, if the test well is to be utilized. Some sand will probably be pumped by the well even at a moderate dis charge.

The tests indicate that the formation at the site of the test well can yield more than the desired $40 \mathrm{gpm}$. A replacement well of different construction or a second well used with the test well should obtain the desired yield. A replacement well must be constructed so that a larger entrance area is obtained, possibly by screening and sand packing some of the formation above the coarse zone perforated in the test well. The fine sand zone directly above this coarse zone (fig. 5) presents a problem, and proper sizing of the screen and sand pack would be necessary to prevent sand pumping.

If two wells are used, they should be spaced at least 100 feet and preferably 200 feet apart. Interference between them should be small at moderate discharges because the source of recharge, the river, is near. The tcst well was drilled in an old alluvium-filled channel and penetrated thicker alluvium than is present in most of the area. The old channel probably follows much the same course as the present river (fig. 6), but its precise location is known only at the test well. Additional test drilling could locate the thicker alluvium more precisely.

PILGRIM CREEK VALLEY TESTS

A yield of about $200 \mathrm{gpm}$ is needed from the Pilgrim Creek valley area by the Park Service for immediate use at the Colter Bay and Jackson Lake Lodge developments. Pumping tests indicated that test well 46-114-29dbd* could supply the immediate needs of $200 \mathrm{gpm}$ and that additional wells in the general area could supply the future needs。

Test well 46-114-29adc* was pumped 24 hours at about $150 \mathrm{gpm}$ with a drawdown of 4 feet. Test well 46-114-29dbc* was pumped at about $130 \mathrm{gpm}$ with a maximum drawdown of 3.6 feet. A discharge of more than 200 gpm could have been obtained from either well by using a larger pump. Both wells were abandoned in favor of test well 46-114-2 9dbd*, which yielded $150 \mathrm{gpm}$ with only 1.5 feet of drawdown. The production well that was subsequently drilled adjacent to test well 46114-29dbd* yielded $270 \mathrm{gpm}$ with 5 feet of drawdown during a 4-hour test.

The water discharged from test well 46114-29dbc* flowed less than 150 feet before it disappeared into the permeable valley-fill deposits. The water returned to the aquifer and interfered with the test. The graph of the drawdown and recovery (fig. 8) shows the influence of the returning water. Within a few minutes after pumping stopped, the water level rose more than a foot above the static level and then declined slowly as the head of returning water declined. The other test wells were near the stream, and most of the water discharged from these wells ran to the stream.

\section{JACKSON LAKE CAMPGROUND TESTS}

Brief bailing tests made during drilling of the first test well (45-115-25bbd) in the Jackson Lake Campground area yielded about 60 gpm from the upper aquifer (sand and gravel unit), but only a trickle of water could be obtained when the casing was perforated. A 
decline in the level of Jackson Lake of about 10 feet between the time of the bailing tests and the perforation of the casing may have caused a sufficient drop in head to account for the loss of water to the well. More probably the loss was caused by the accidental sealing off of the formation near the casing during drilling operations. The lower aquifer (sand unit) was pumped at $20 \mathrm{gpm}$ for 24 hours, but attempts to increase the yield were unsuccessful. Because a minimum yield of $30 \mathrm{gpm}$ was desired, the well was filled in and abandoned.

The second test well (45-115-25bca) was pumped at about $115 \mathrm{gpm}$ for 24 hours with 11 feet of drawdown; this well could probably yield $200 \mathrm{gpm}$. The casing was perforated opposite both aquifers (fig. 5). During the pumping test, all the water discharged from the well probably came from the upper aquifer because the water level did not drop below the head in the lower aquifer. The head in the lower aquifer is several tens of feet less than that in the upper; so, in the well, water is continually being discharged from the upper aquifer into the lower. The lower aquifer should be sealed off to prevent continued leakage, and, if more water is needed, the aquifers should be tapped separately.

\section{LIZARD POINT CAMPGROUND TEST}

A yield of about $15 \mathrm{gpm}$ is desired by the Park Service for proposed facilities at Lizard Point Campground. Yields larger than $15 \mathrm{gpm}$ could have been obtained from either of the test wells in the area. Test well 47115-29dca* was bailed at about $25 \mathrm{gpm}$ but was abandoned in favor of test well 47-115$32 \mathrm{abb}^{*}$, which had a much higher yield. Test well 47-115-32abb* was pumped for 24 hours at about $96 \mathrm{gpm}$ with 5 feet of drawdown. This well probably has a maxium yield of more than $200 \mathrm{gpm}$.

\section{QUALITY OF GROUND WATER}

Thirteen water samples were collected from 11 wells in Quaternary deposits, and 1 sample was collected from a well in the Bivouac Formation. Results of the Chemical analyses determined by the Geological Survey are given in table 6. The water is of generally good quality for drinking and most other purposes. (Well 45-114-26abb1, which taps lacustrine(?) sand, had a dissolved-solids content of $321 \mathrm{ppm}$ (parts per million); all other samples had dissolved solids ranging from 87 to $145 \mathrm{ppm}$. No samples could be obtained from pre-Quaternary rocks except from the Bivouac Formation; water from some older rocks may have a much higher dissolved-solids content than the sampled waters.

Estimates of dissolved solids in a water can be made from the specific conductance of the water. (Specific conductance is expressed in reciprocal ohms per centimeter times $10^{6}$-micromhos per centimeter at $25^{\circ} \mathrm{C}$.) The dissolved-solids content in parts per million of water derived from Quaternary deposits of the area is approximately 60 percent of the specific conductance. Field determinations of specific conductance were made wherever possible and are shown in table 3. More accurate laboratory determinations are given in table 6 .

\section{POSSIBILITIES FOR FUTURE GROUND-WATER DEVELOPMENT}

Additional ground water may be obtained in many parts of the project area for domestic, stock, or small public supplies. Larger public supplies may be developed in parts of the Pilgrim Creek valley.

For the purpose of the following discussion, the terms "small," "moderate," and "large" quantities of water have been given the arbitrary values less than $20 \mathrm{gpm}, 20$ to $80 \mathrm{gpm}$, and greater than $80 \mathrm{gpm}$, respectively.

\section{DEPOSITS OF QUATERNARY AGE}

Quaternary deposits are the most promising sources of additional ground water. Seven areas where they might be tapped are outlined on plate 1 and are discussed below.

\section{AREA 1}

Yields of as much as 1,000 gpm may be expected from wells in parts of the Pilgrim Creek valley (area 1 on pl. 1). More than 100 feet of saturated highly permeable valley fill is known and 200 feet or more may be present. Because of the relief of the bedrock surface underlying the valley fill, thickness of the fill will differ considerably from place to place. Wells should penetrate the greatest thickness of saturated fill available because water-level fluctuations are extreme (table 4). When recharge decreases during dry periods, several tens of feet of the valley fill may be dewatered; shallow wells may 
Table 6. - Chemical analyses of ground water east of Jackson Lake

Geologic source: Qa, older alluvium; Qal, younger alluvium; Q1, lacustrine deposits; QTb, Bivouac Formation; Qu, undifferentiated rocks of Quaternary age.

[Results in parts per million. Analyses by U.S. Geological Survey]

\begin{tabular}{|c|c|c|c|c|c|c|c|c|c|c|c|c|c|c|c|c|c|c|c|c|c|c|c|c|c|c|c|c|}
\hline \multirow[b]{2}{*}{ Well } & \multirow[b]{2}{*}{ 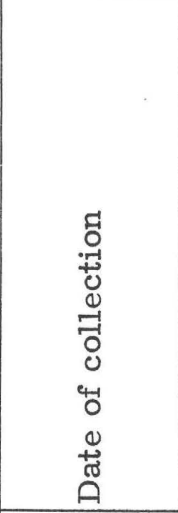 } & \multirow{2}{*}{ 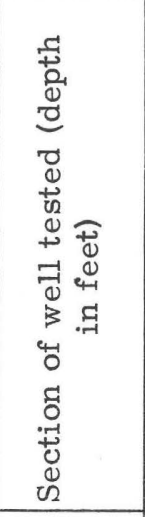 } & \multirow[b]{2}{*}{$\begin{array}{c}0 \\
0 \\
\vdots \\
5 \\
0 \\
0 \\
0 \\
01 \\
0.0 \\
0 \\
0 \\
0 \\
0 \\
0\end{array}$} & \multirow[b]{2}{*}{ 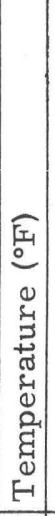 } & \multirow[b]{2}{*}{ 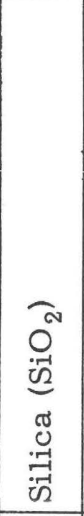 } & \multicolumn{2}{|c|}{ Iron $(\mathrm{Fe})$} & \multirow[b]{2}{*}{ 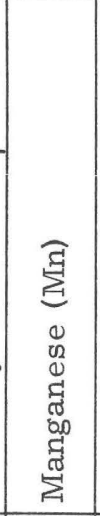 } & \multirow[b]{2}{*}{ 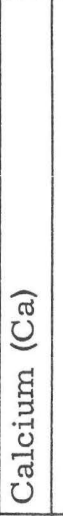 } & \multirow[b]{2}{*}{ 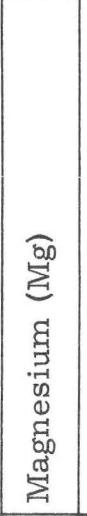 } & \multirow[b]{2}{*}{ 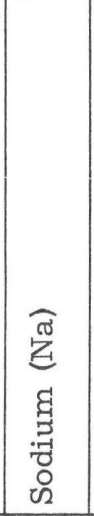 } & \multirow[b]{2}{*}{ 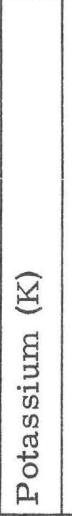 } & \multirow[b]{2}{*}{ 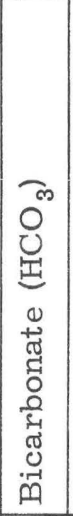 } & \multirow[b]{2}{*}{ 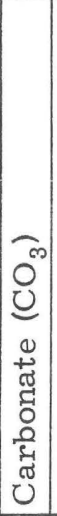 } & \multirow[b]{2}{*}{ 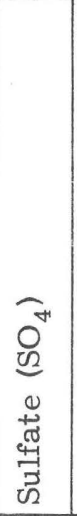 } & \multirow[b]{2}{*}{ 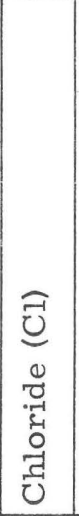 } & \multirow[b]{2}{*}{ 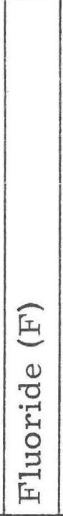 } & \multirow[b]{2}{*}{ 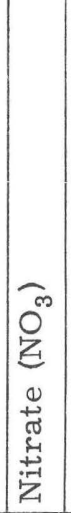 } & \multirow[b]{2}{*}{ 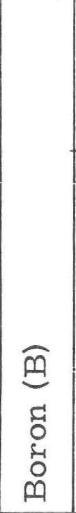 } & \multicolumn{2}{|c|}{$\begin{array}{l}\text { Dis- } \\
\text { solved } \\
\text { solids }\end{array}$} & \multicolumn{2}{|c|}{$\left|\begin{array}{c}\text { Hard- } \\
\text { ness } \\
\text { as } \\
\mathrm{CaCO}_{3}\end{array}\right|$} & \multirow[b]{2}{*}{ 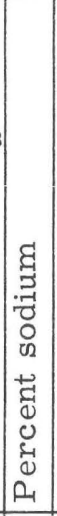 } & \multirow{2}{*}{ 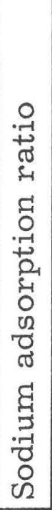 } & \multirow{2}{*}{ 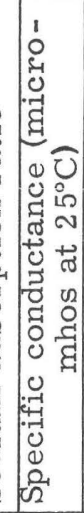 } & \multirow[b]{2}{*}{ 盗 } & \multirow[b]{2}{*}{ 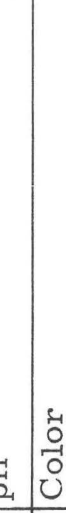 } \\
\hline & & & & & & 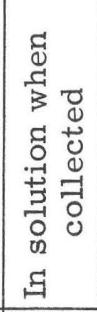 & 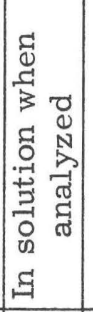 & & & & & & & & & & & & & 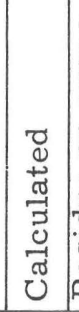 & 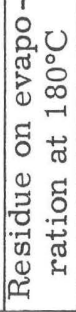 & 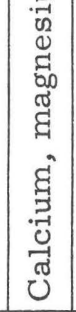 & 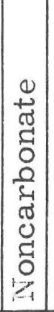 & & & & & \\
\hline 45-114- & & & & & & & & & & & & & & & & & & & & & & & & & & & & \\
\hline $\begin{array}{l}19 \mathrm{baa} \\
19 \mathrm{bdc}\end{array}$ & $\begin{array}{r}10-20-60 \\
8-15-61\end{array}$ & $\begin{array}{c}202-216 \\
<98\end{array}$ & $\begin{array}{l}\mathrm{QTb} \\
\mathrm{Qu}\end{array}$ & -- & $\begin{array}{l}27 \\
38\end{array}$ & $-\overline{-n}$ & $\begin{array}{r}0.00 \\
.02\end{array} \mid$ & 0.00 & $\begin{array}{l}20 \\
33\end{array}$ & $\begin{array}{l}4.4 \\
4.3\end{array}$ & $\begin{array}{l}5.6 \\
3.5\end{array}$ & $\begin{array}{l}2.1 \\
3.0\end{array} \mid$ & $\begin{array}{r}90 \\
130\end{array}$ & $\begin{array}{l}0 \\
0\end{array}$ & $\begin{array}{l}2.5 \\
5.6\end{array}$ & $\begin{array}{l}0.0 \\
1.0\end{array}$ & $\left|\begin{array}{r}0.2 \\
.3\end{array}\right|$ & $\begin{array}{r}4.2 \\
.7\end{array}$ & $\left|\begin{array}{r}0.04 \\
.01\end{array}\right|$ & 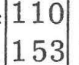 & $\begin{array}{l}130 \\
145\end{array} \mid$ & $\begin{array}{r}68 \\
100\end{array}$ & $\begin{array}{l}0 \\
0\end{array}$ & $\begin{array}{r}15 \\
7\end{array}$ & $\begin{array}{r}0.3 \\
.2\end{array}$ & $\left|\begin{array}{l}167 \\
209\end{array}\right|$ & $\begin{array}{l}7.0 \\
7.3\end{array}$ & $\begin{array}{l}2 \\
3\end{array}$ \\
\hline $23 \mathrm{ccd}$ & $7-9-61$ & $28-30$ & $\begin{array}{l}\text { Qal, } \\
\text { Q1(?) }\end{array}$ & 43 & 14 & .21 & .00 & .04 & 31 & 4.3 & 9.0 & 1.1 & 120 & 0 & 6.0 & 2.7 & .4 & 1.0 & .05 & 129 & 129 & 95 & 0 & 17 & .4 & 227 & 7.5 & 0 \\
\hline $\begin{array}{c}26 \mathrm{abb}^{1} \\
45-115-\end{array}$ & $6-14-61$ & $<60$ & Q1(?) & -- & 24 & ${ }^{2} 6.9$ & .01 & 2.07 & 73 & 18 & 20 & 3.5 & 341 & 0 & 4.7 & 12 & .2 & .1 & .03 & 324 & 321 & 255 & 0 & 14 & .5 & 546 & 7.5 & 4 \\
\hline $24 \mathrm{cdd} \ldots$ & $8-15-61$ & $<160$ & $\mathrm{Qu}$ & $1--1$ & 21 & .04 & .02 & .00 & 17 & 2.8 & 11 & 1.2 & 71 & 0 & 13 & 5.9 & .6 & .4 & .04 & 107 & 104 & 54 & 0 & 30 & .7 & 7162 & 7.0 & -- \\
\hline $25 \mathrm{bbd} \ldots$ & $7-20-61$ & ${ }^{3} 152$ & $\mathrm{Qu}$ & 43 & 26 & .03 & .03 & .01 & 24 & 5.1 & 14 & 3.0 & 113 & 0 & 15 & 6.6 & .8 & .0 & .09 & 151 & 141 & 81 & 0 & 26 & .7 & 7225 & 7.4 & 3 \\
\hline $25 \mathrm{bca} \ldots$ & $8-11-61$ & $59-68$ & $\mathrm{Qu}$ & 44 & 19 & .09 & .06 & 2.16 & 21 & 2.1 & 12 & 1.8 & 80 & 0 & 15 & 6.2 & .6 & .9 & .07 & 118 & 109 & 61 & 0 & 29 & .7 & 7177 & 7.4 & 3 \\
\hline $\begin{array}{l}\text { Do } \ldots \ldots \\
46-114-\end{array}$ & $8-15-61$ & $\begin{array}{c}59-68 \\
159-160 \\
(?)\end{array}$ & Qu & 43 & 21 & .04 & .03 & .00 & 20 & 3.2 & 11 & 2.7 & 80 & 0 & 13 & 6.2 & .6 & .7 & .08 & 118 & 109 & 63 & 0 & 26 & .6 & 177 & 7.2 & 4 \\
\hline $29 a d c^{*} \ldots$ & $6-6-61$ & $26-55$ & Qa & 40 & 8.9 & .05 & .00 & .00 & 28 & 4.2 & 4.3 & .7 & 110 & 0 & 3.0 & .0 & .1 & 1.7 & .01 & 105 & 104 & 87 & 0. & 10 & .2 & 186 & 7.3 & 0 \\
\hline $29 \mathrm{dbc}^{*} \ldots$ & $6-28-61$ & $36-56$ & Qa & 40 & 11 & .00 & .00 & .00 & 23 & 2.6 & 2.6 & .5 & 84 & 0 & 2.5 & .0 & .1 & 1.0 & .01 & 84 & 87 & 68 & 0 & 8 & .1 & 147 & 7.0 & 0 \\
\hline $29 \mathrm{dbd}^{*} \ldots$ & $6-23-61^{4}$ & $31-134$ & Qa & 39 & 8.5 & .05 & .00 & .00 & 28 & 3.2 & 3.7 & .6 & 104 & 0 & 3.3 & .0 & .1 & .2 & .01 & 99 & 98 & 83 & 0 & 9 & .2 & 176 & 7.2 & 0 \\
\hline Do & $6-24-61^{4}$ & $31-134$ & $Q a$ & 39 & 8.1 & .05 & .01 & .00 & 28 & 3.9 & 3.7 & .6 & 109 & 0 & 1.5 & .0 & .1 & .2 & .01 & 100 & 104 & 86 & 0 & 8 & .2 & 183 & 7.2 & 0 \\
\hline $\begin{array}{l}22 \mathrm{adb} \ldots \\
47-115-\end{array}$ & $8-17-61$ & $101-163$ & $\mathrm{Qu}$ & $\ldots$ & 16 & .04 & .01 & .01 & 37 & 7.2 & 3.7 & 1.8 & 154 & 0 & 8.8 & .7 & .2 & .0 & .01 & 151 & 141 & 122 & 0 & 6 & .2 & 245 & 8.1 & 3 \\
\hline $32 a b b * \ldots$ & $7-26-61$ & $68-88$ & Qa & 41 & 18 & .03 & .03 & .00 & 33 & 5.8 & 3.6 & 1.0 & 135 & 0 & 5.0 & .9 & .2 & .3 & .00 & 134 & 130 & 106 & 0 & 7 & .2 & 218 & 7.8 & 3 \\
\hline
\end{tabular}

1 Water had been stored in pressure tank before sampling; concentrations of iron and some other constituents may have been affected.

2 Exceeds limits recommended by the U.S. Public Health Service (1962) for public drinking water.

${ }^{3}$ Water entered well through bottom of casing; no open hole below casing.

4 Sampled at beginning and end of 24 -hour pumping test. 
decrease in yield or go dry. Test drilling prior to construction of permanent wells is recommended.

\section{AREA 2}

Two deep flowing wells east of Jackson Lake Dam reportedly penetrate clay and fine sand, but no written well logs are available in area 2 . The valley fill is probably composed mostly of fine materials up to several hundred feet thick, which should yield small to moderate quantities of water. Some coarser, more permeable materials, which would yield greater quantities of water, may be present at depth in parts of the area. Surface deposits in most of the area are of low permeability, and water is semiconfined; wells in topographically low parts of the area should flow.

Bedrock is exposed near Jackson Lake Lodge, and the valley fill east of the lodge is probably much thinner than els ewhere in area 2. Large quantities of water have been obtained from springs in the seep area east of the lodge and additional supplies could probably be developed in that locality.

\section{AREA 3}

The nature and thickness of the valley fill is unknown in most of area 3. A few shallow wells have derived water from gravel; some have gone dry during the winter. Valley fill underlying the gravel probably is mostly fine grained and moderately thick, becoming thicker and finer grained toward the west. Additional shallow wells may yield small to moderate quantities of water. More dependable yields might be obtained from deeper wells: Test drilling before installation of permanent wells is recommended.

In sec. 1 and 12, T. 45 N., R. 114 W., partly reworked glacial outwash will probably yield small to moderate water supplies where sat urated. The stream draining Two Ocean Láke has cut deeply into the outwash in sec. 12 and has drained much of the material. The stream does not flow throughout the year in its lower reach, and wells must be drilled many feet below the level of the stream to obtain a perennial water supply.

\section{AREA 4}

Small to moderate yields of water may be obtained from alluvial gravel in parts of area
4 , but, in much of the area, the saturated gravel is too thin to form a good aquifer. The water table closely follows the stages of the rivers (fig. 7), and wells that penetrate only a thin saturated zone may have low yields and may go dry during low river stages.

In much of area 4 lacustrine deposits underlie the alluvium to depths of as much as 100 feet. Most of the lacustrine deposits are poorly permeable, but some coarser wellsorted zones will yield small quantities of water. The water in these deposits is of poorer quality than that in the alluvium but is suitable for most uses,

The alluvial fan in the southern part of area 4 is probably composed predominantly of fine materials. The deposits are probably of low permeability but may yield small amounts of water.

\section{AREA 5}

Moderate to large quantities of ground water can probably be obtained at most locations in area 5. At the south tip of Lizard Point in the vicinity of test well 47-115$32 \mathrm{abb}^{*}$, yields of as much as $100 \mathrm{gpm}$ can be expected. The thickness of the saturated permeable material is probably greatest toward the southwest. Along the east side of Lizard Point, yields will be smaller, but moderate quantities of water are probably available at most locations. Wells drilled between Lizard Point and Lizard Creek will probably yield moderate quantities of water, but as test holes have not been drilled in that locality, the nature and thickness of the material is unknown.

\section{AREA 6}

In much of area 6 glacial drift covers undifferentiated Quaternary deposits that will probably yield small to moderate quantities of water. The depth of a well depends on the types of materials penetrated and the altitude of the well site. Topographically high areas may be drained, and wells in these areas must be drilled deeper to penetrate saturated deposits. Small to moderate quantities of water may be derived from shallow wells in glacial deposits near Arizona Creek and at other favorable localities.

\section{AREA 7}

Several wells along the southeast edge of Jackson Lake in area 7 yield moderate to large quantities of water. Little is known of 
the extent of the aquifers, but possibilities for the development of additional wells in this area seem to be good.

\section{DEPOSITS OF PRE-QUATERNARY AGE}

Several pre-Quaternary formations are potential aquifers (table 1), but only the Biv ouac Formation has been tested in the project area. West of Signal Mountain the Bivouac Formation may yield small quantities of water to deep wells. Of the other pre-Quaternary rocks, the Harebell Formation and Bacon Ridge Sandstone are the most promising potential aquifers. Because of the complexity of the geology, each proposed well site should be investigated in as much detail as possible before drilling.

\section{SELECTED REFERENCES}

Blackwelder, Elito, 1915, Post-Cretaceous history of the mountains of central western Wyoming: Jour. Geology, v. 23, p. 97-117, 193-217, 307-340.

Bradley, F. H., 1872, Geologic report of the Snake River Division: U.S. Geol. Survey of the Terr.6th Ann. Rept., p. 191-271 [1873].

Foster, H. L., 1947, Paleozoic and Mesozoic stratigraphy of northern Gros Ventre Mountains and Mount Leidy Highlands, Teton County, Wyoming: Am. Assoc. Petroleum Geologists Bull., v. 31, no. 9, p. 1537-1593.

Fryxell, F. M., 1930, Glacial features of Jackson Hole, Wyoming: Augustana Libr. Pub. no. 13, 129 p., Rock Island, Ill.

Hem, J. D., 1959, Study and interpretation of the chemical characteristics of natural water: U.S. Geol. Survey Water-Supply Paper 1473, 269 p.

Holmes, G. W., and Moss, J. H., 1955, Pleistocene geology of the southwestern Wind River Mountains, Wyoming: Geol. Soc. America Bull., v. 66, no. 6, p. 629-654.

Love, J. D., 1947 Tertiary stratigraphy of the Jackson Hole area, northwestern Wyoming: U.S. Geol. . Survey Oil and Gas Inv. (Prelim.) Chart OC-27.

1956a, New geologic formation names in Jackson Hole, Teton County, northwestern Wyoming: Am. Assoc. Petroleum Geologists Bull., v. 40, no. 8, p. 1899-1914. 1956b, Cretaceous and Tertiary stratigraphy of the Jackson Hole area, northwest Wyoming, in Wyoming Geol. Assoc. Guidebook 11th Ann. Field Con., Jackson Hole, Wyoming, 1956: p. 76-94.

- 1956c, Summary of geologic history of Teton County, Wyoming, during late
Cretaceous, Tertiary, and Quaternary times, in Wyoming Geol. Assoc. Guidebook 11th Ann. Field Conf., Jackson Hole, Wyoming, 1956: p. 140-150.

- 1956d, Geologic map of Teton County, Wyoming, in Wyoming Geol. Assoc. Guidebook 11th Ann. Field Conf. Jáckson Hole, Wyoming, 1956.

1961, Reconnaissance study of Quaternary faults in and south of Yellowstone National Park, Wyoming: Geol. Soc. America Bull., v. 72, no. 12, p. 1749-1764.

Love, J. D., Duncan, D. C., Berquist, H. R., and Hose, R. K., 1948, Stratigraphic sections of Jurassic and Cretaceous rocks in the Jackson Hole area, northwestern Wyoming: Wyoming Geol. Survey Bull. no. 40, $48 \mathrm{p}$.

Love, J. D., Hose, R. K., Weitz, J. L., Duncan, D. C., and Bergquist, H. R., 1951, Stratigraphic sections of Cretaceous rocks in northeastern Teton County, Wyoming: U.S. Geol. Survey Oil and Gas Inv. Chart OC -43 .

Love, J. D., and Montagne, John de la, 1956 , Pleistocene and Recent tilting of Jackson Hole, Teton County, Wyoming, in Wyoming Geol. Assoc. Guidebook 11th Ann. Field Conf., Jackson Hole, Wyoming, 1956: p. 169-178.

Love, J. D., and Taylor, D. W., 1962, Faulted Pleistocene strata near Jackson, Northwestern Wyoming, Short Papers in Geology and Hydrology: U.S. Geol. Survey Prof. Paper 450-D, art. 160, p. D136-D139.

Montagne, John de 1a, and Love, J. D., 1957, Giant glacial grooves and their significance in the Jackson Hole area, Wyoming [abs.]: Geol. Soc. America Bull., v. 68, no. 12 , pt. 2, p. 1861 .

Richmond, G. M., 1948, Modification of Blackwelder's sequence of Pleistocene glaciation in the Wind River Mountains, Wyoming [abs.]: Geol. Soc. America Bull., v. 59 , no. 12 , pt 2 , p. 1400-1401.

1962, Three pre-Bull Lake tills in the Wind River Mountains, Wyoming, Short Papers in Geology and Hydrology: U.S. Geol. Survey Prof. Paper 450-D, art. 159, p. D132-D136.

St. John, O, H., 1878, Geologic report of the Teton division: U.S. Geol. Survey of the Terr. 11th Ann. Rept., p. 321-508 [1879].

U.S. Public Health Service, 1962, Drinking water standards: Public Health Service Pub. 956, 61 p. 